EGG--2185

DE82 012770

$$
\text { A. MOTICE }
$$

POATIONS OF THIS REPORT ARE ILLEGIBLE. Whas been reproduced from the sest avaitablo expy to permit the bracdest possible availability.

\title{
MONITORING WELL SYSTEMS IN GEOTHERMAL AREAS
}

\author{
Ben E. Lofgren \\ Jack O'Rourke \\ Robert Sterrett \\ John Thackston \\ Dale Fain
}

Published March 1982

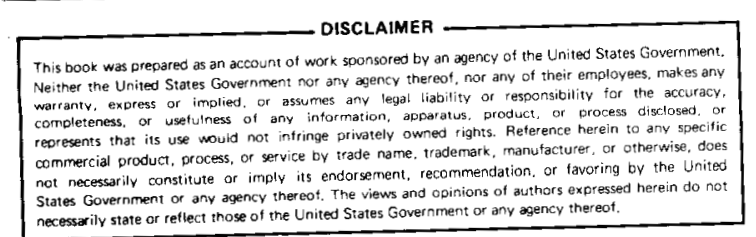

\section{Woodward-Clyde Consultants}

Prepared for EG8G Idaho, Inc.

Under Subcontract No. K-7810

and the U.S. Department of Energy

Idaho Operations Office

Under DOE Contract No. DE-AC07-76ID01570

DISTRABTTOH OF THIS DOCUMENT IS IN!IMHTED 


\section{DISCLAIMER}

This report was prepared as an account of work sponsored by an agency of the United States Government. Neither the United States Government nor any agency Thereof, nor any of their employees, makes any warranty, express or implied, or assumes any legal liability or responsibility for the accuracy, completeness, or usefulness of any information, apparatus, product, or process disclosed, or represents that its use would not infringe privately owned rights. Reference herein to any specific commercial product, process, or service by trade name, trademark, manufacturer, or otherwise does not necessarily constitute or imply its endorsement, recommendation, or favoring by the United States Government or any agency thereof. The views and opinions of authors expressed herein do not necessarily state or reflect those of the United States Government or any agency thereof. 


\section{DISCLAIMER}

Portions of this document may be illegible in electronic image products. Images are produced from the best available original document. 


\section{ABSTRACT}

The ability to monitor the injection of spent geothermal fluids at reasonable cost might be greatly improved by use of multiple-completion techniques. Several such techniques, identified through contact with a broad range of experts from the groundwater and petroleum industries, are evaluated relative to application in the typical geologic and hydrologic conditions of the Basin and Range Province of the Western United States.

Three basic monitor well designs are suggested for collection of pressure and temperature data: Single standpipe, multiple standpipe, and closed-system piezometers. A fourth design, monitor well/injection well dual completions, is determined to be inadvisable. Also, while it is recognized that water quality data is equally important, designs to allow water sampling greatly increase costs of construction, and so such designs are not included in this review.

The single standpipe piezometer is recom-

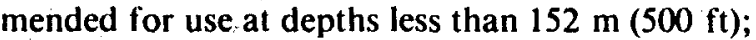
several can be clustered in one area to provide information on vertical flow conditions. At depths greater than $152 \mathrm{~m}$ (500 ft), the multiplecompletion standpipe and closed-system piezometers are likely to be more cost effective. Unique conditions at each monitor well site may necessitate consideration of the single standpipe piezometer even for deeper completions. 


\section{FOREWORD}

The Geothermal Technical Assistance Program was developed under the premise that the majority of groups or individuals with available geothermal resources do not have the experience or manpower necessary to do a preliminary engineering and economic feasibility evaluation for geothermal energy projects. In order to disseminate technical information and to facilitate expanded use of geothermal energy resources, assistance was provided through FY-1981 in a consulting format on a first-come, staff-andfunds-available basis. Technical assistance can relate to conceptualization; engineering; economics; water chemistry implications for environmental, disposal, and material selection considerations; and planning and development strategies. This report is one of a series adapted from consultation provided to requesters either through in-house efforts or through limited efforts subcontracted to local engineering firms. The Geothermal Technical Assistance (GTA) Reports in this series, which are listed below, will be available for purchase early in 1982 by those with interest in specific geothermal applications from the U.S. National Technical Information Service:

U.S. Department of Commerce,

National Technical Information Service,

5285 Port Royal Road,

Springfield, VA 22161,

(703) $557-4650$

\begin{tabular}{|c|c|}
\hline $\begin{array}{c}\text { GTA } \\
\text { Report Number }\end{array}$ & $\begin{array}{c}\text { EG\&G } \\
\text { Report Number }\end{array}$ \\
\hline 1. & ${ }^{*}$ EGG-GTH-5512 \\
\hline 2. & *EGG-GTH-5521 \\
\hline 3. & *EGG-GTH-5573 \\
\hline 4. & *EGG-GTH-5574 \\
\hline 5. & *EGG-GTH-5575 \\
\hline 6. & *EGG-GTH-5599 \\
\hline
\end{tabular}

7.

EGG-GTH-5617

Aquaculture Facility Potential at Boulder Hot Springs, Boulder, Montana

Preliminary Geothermal Disposal Considerations, State Health Laboratory, Boise, Idaho

Geothermal Conversion at Veterans Hospital, Boise, Idaho

Geothermal Applications for Highway Rest Areas

Geothermal Applications for a Tannery

Preliminary Conceptual Design for Geothermal Space Heating Conversion of School District 50 Joint Facilities at Pagosa Springs, Colorado

Selected Geothermal Technical Assistance Efforts (comprising short descriptions of ten space heating projects, five district heating projects, and three heat exchanger projects)

8.

*EGG-2137

Geothermal Source Potential and Utilization for Methane Generation and Alcohol Production (subcontractor report)

9.

*EGG-2138

Geothermal Source Potential and Utilization for Alcohol Production (subcontractor report) 
GTA

Report Number

10.

11.

*EGG-2144

12.

*EGG-2145

13.

EGG-2146

14.

EGG-2147

15.

*EGG-2148

16.

EGG-2149

17.

18.

19.

20.

21.

22.

23.

EGG-2156

24.

*EGG-GTH-5739

25.

*EGG-GTH-5740
Title

Potential Geothermal Energy Applications for Idaho Elks Rehabilitation Hospital (subcontractor report)

Technical Assistance Report on a Geothermal Heating Utility for Lemmon, South Dakota (subcontractor report)

Economic Analysis for Utilization of Geothermal Energy by North Dakota Concrete Products Company (subcontractor report)

Geothermal Feasibility Analysis II for Polo School District No. 29-2, South Dakota (subcontractor report)

Preliminary Feasibility Study of Heating and Cooling Alternatives for Nebraska Western College, Scottsbluff, Nebraska (subcontractor report)

Inventory of Thermal Springs and Wells Within a OneMile Radius of Yucca Lodge, Truth or Consequences, New Mexico (subcontractor report)

Space Heating for Spa Facilities at Ojo Caliente, New Mexico (subcontractor report)

Space Heating for Office Building at Glenwood Springs, Colorado (subcontractor report)

District Heating for Subdivision in Dickinson, North Dakota (subcontractor report)

Space Heating for Subdivision in Truth or Consequences, New Mexico (subcontractor report)

Space Heating for Veterans Administration Medical Center, Marlin, Texas (subcontractor report)

District Heating for Subdivision in Castle Rock, Colorado (subcontractor report)

Space Heating for Twin Lakes School Near Gallup, New Mexico (subcontractor report)

Pumping Tests of Well Campbell Et Al. No. 2, Gila Hot Springs, Grant County, New Mexico (subcontractor report)

Geothermal Deicing of Bridge Structures

Assessment of a Geothermal Application at Tucson, Arizona 
GTA

Report Number

26.

EGG-

GTH-5741

27.

28.

EGG-GTH-5779

EGG-GTH-5804
Title

Heat Pump Systems for Spring Creek, Montana

Pipe Selection Guide

An Overview of Engineering and Agricultural Design Considerations of the Raft River Soil Warming Heat Dissipation Experiment

*Published as of $3 / 15 / 82$ 


\section{PREFACE}

This report was prepared for EG\&G Idaho by Woodward-Clyde Consultants on Subcontract K-7810 under the Department of Energy Environmental Support Program. It is being reissued as an EG\&G formal report in order to make it available to others that may be interested in this subject. 
MONITORING WELL SYSTEMS IN

GEOTHERMAL AREAS

Prepared for

EG\&G Idaho, Inc. P.O. Box 1625

Idaho Falls, Idaho 83415

by

Ben E. Lofgren

Jack O'Rourke Robert Sterrett

John Thackston

Dale Fain

WOODWARD-CLYDE CONSULTANTS

3 Embarcadero Center, Suite 700

San Francisco, California 94111 
LIST OF TABLES

LIST OF FIGURES

INTRODUCTION

OBJECTIVES

TASKS OF STUDY

GEOLOGIC SETTING AND ASSOCIATED DRILLING PROBLEMS

CRI'TERIA FOR DESIGN

CRITERIA FOR EVALUATION OF MONITORING TECHNIQUES

PIEZOMETER TYPES

$\begin{array}{ll}\text { Open Standpipe Piezometers } & 7\end{array}$

$\begin{array}{ll}\text { Closed System Piezometers } & 8\end{array}$

Vibrating-Wire Piezometers 8

$\begin{array}{ll}\text { Pneumatic Piezometers } & 10\end{array}$

$\begin{array}{ll}\text { Portable Piezometer Probes } & 11\end{array}$

WELL SEALING TECHNIQUES $\quad 12$

$\begin{array}{ll}\text { Grouting } & 12\end{array}$

Permeable Grouted Seals 14

$\begin{array}{ll}\text { Filter Zones } & 15\end{array}$

PERMANENT INSTALLATIONS 17

MULTIPLE-COMPLETION WELLS 20

COMBINED INJECTION WELL AND MONITORING

$\begin{array}{ll}\text { INSTALLATIONS } & 21\end{array}$

$\begin{array}{ll}\text { WATER QUALITY SAMPLING } & 23\end{array}$ 
PETROLEUM INDUSTRY TECHNIQUES

SURVEY OF PRACTICE IN MONITORING MULTI-LAYERED AQUIFER SYSTEMS 26

Organizations Using Multiple-Completion Wells 28

U.S. Bureau of Reclamation 28

U.S. Geological Survey 30

U.S. Corps of Engineers 33

Other Multiple-Completion Users 34

Other Experts Contacted 35

Drilling Costs $\quad 36$

$\begin{array}{ll}\text { CONCLUSIONS AND RECOMMENDATIONS } & 37\end{array}$

SINGLE-STANDPIPE PIEZOMETER DESIGN 38

MULTIPLE-STANDPIPE PIEZOMETER DESIGN 39

CLOSED-SYSTEM PIEZOMETER DESIGN

$\begin{array}{ll}\text { OTHER RECOMMENDATIONS } & 40\end{array}$

$\begin{array}{ll}\text { REFERENCES } & 41\end{array}$

TABLES

FIGURES 


\section{LIST OF TABLES}

Table No. Title

1 Cost Estimate of Completion System

\section{LIST OF FIGURES}

Figure No. Title

1

2

3

4

5

6

7

8

9

10

11

12

Shallow Standpipe piezometer Installation

Details

Multiple-Unit Standpipe Piezometer

Electric Vibrating-Wire Piezometer

Pneumatic Piezometer

Portable Piezometer Probe System

Example of Need for Grout Seals in a MultipleCompletion Well

Summary of Grout Performance for Moderate Temperature Location $\left(\mathrm{T}<100^{\circ} \mathrm{C}\right)$

piezometer Errors for "Permeable" Grout Plug Seals

Multiple-Completion Well Example

Schematics of Air-lift Water-Quality Samplers

Sketch of Packer System

Schematic of Three Monitoring system Designs 
MONITORING WELL SYSTEMS IN GEOTHERMAL AREAS

INTRODUCTION

OBJECTIVES

EG\&G Idaho, under contract with the U.S. Department of Energy, engaged Woodward-Clyde Consultants (WCC) to: 1) study construction methods for both monitoring and injection wells in geothermal areas; and 2) recommend multiple-completion designs for instrumented wells that would monitor fluid changes in several aquifers of different depths overlying a basin-and-range-type geothermal reservoir system.

TASKS OF STUDY

Three tasks constitute the activities of this project. They are:

1. A review of construction methods for monitoring wells that are completed at more than one depth and that tap more than one aquifer. The possibility of monitoring pressure, temperature, and water chemistry at each selected depth zone was explored.

2. A review of construction methods for injection wells, and the possibility of monitoring formation pressure and/or water chemistry at depths shallower than the receiving zone, using special instrumentation outside the well casing. Inherent in WCC's considerations was the ability to measure possible fluid migration 
in the borehole outside the casing. Preventative measures to minimize the exchange of aquifer waters were also considered.

3. Generic designs for single- and multiple-well completions were made. These designs were keyed to a Basin-and-Range-type geologic setting.

GEOLOGIC SETTING AND ASSOCIATED DRILLING PROBLEMS

As stated above, objectives of the study were to investigate monitoring well systems suitable for the Basin and Range province of the western United States. This province is characterized by faulted, closed basins between mountain ranges. The basins can be filled with several thousand feet of cemented to uncemented (unconsolidated) stream- (fluvial-) deposited sediments. These sediments are generally poorly sorted, with grain-size distributions ranging from clays and silts to gravels. In general, grain size decreases from the valley edge, adjacent to the mountains, to the center of the valley.

During the Pleistocene, when world-wide climates were cooler and more moist, many of the basins in this province were repeatedly filled with lakes. At the end of the Pleistocene, as precipitation decreased and annual evaporation rates increased, the water in many of the lakes eventually evaporated. Consequently, fine-grained lacustrine deposits are frequently found interbedded with alluvial sediments.

Drilling in the Basin and Range province poses many problems. The first is the possibility of encountering large boulders during drilling. This situation is more likely to 
happen if drilling is performed close to the edge of the valley and decreases progressively towards the center of the basin. Large boulders may require relocating the borehole.

A second problem is the potential for loss of drilling fluid circulation. Such a problem would happen when a very permeable zone is encountered. The solution is to use higher viscosity fluids or attempt to plug the zone with cement.

Hole stability in unconsolidated sediments may also pose a problem. This situation can be controlled through the proper use of drilling muds. The use of heavier mud weights or an increase in the fluid level in the borehole are two techniques to prevent hole collapse. If the borehole is not properly developed after drilling, mud contamination of the formation could impact the quality of water samples taken for chemical analyses.

CRITERIA FOR DESIGN

In order to prepare cost estimates for the tasks involved and to properly scope equipment needed to perform the required tasks, the following criteria were established for this study:

- Four aquifers are to be measured.

o The tops of the aquifers are $457 \mathrm{~m}(1500 \mathrm{feet}), 305 \mathrm{~m}$ (1000 feet), $152 \mathrm{~m}(500$ feet), and $9 \mathrm{~m}$ (30 feet) below land surface.

- All aquifers are $15.2 \mathrm{~m}$ (50 feet) thick.

o The maximum temperature of injected water is $65^{\circ} \mathrm{C}$ $\left(150^{\circ} \mathrm{F}\right)$. 
- The maximum temperature of aquifer water is $18^{\circ} \mathrm{C}$ $\left(65^{\circ} \mathrm{F}\right)$.

- All drilling is in gravels, sands, silts, and clays. No basalts or large boulders are present; thus, there is no potential for loss of circulation.

- The pressure head in any aquifer can be above the top of the aquifer, but not above the land surface; hence, there are no flowing wells.

- The performance life of the monitoring equipment should be 10 years.

- Injection interval for geothermal fluids is below a depth of $1219 \mathrm{~m}$ ( 4000 feet).

The parameters to be monitored for this study are pressure, temperature, and water quality. The principal parameters are pressure and temperature; although water quality in the aquifers above the injection zone is important, its priority for present monitoring needs is reduced. It is assumed that pressure and temperature changes would preceed or accompany chemical changes and, hence, are the basic parameters that need to be monitored. This criterion will significantly impact the final design of the monitoring system because detailed well development techniques that may involve costly downhole pumping systems are not emphasized in this study.

CRITERIA FOR EVALUATION OF MONITORING TECHNIQUES

The total cost and effectiveness of the monitoring system are assumed to be the most important considerations incorporated into any multiple-completion well design. WCC investigated a 
variety of designs in order to demonstrate several different ways for achieving the desired monitoring objectives. However, among the designs and their associated costs, there is a high degree of variability. In all cases, the designs recommended will achieve a level of technically acceptable accuracy.

wCC also investigated commercial monitoring systems that were judged to be technically capable of monitoring multiple aquifers and obtaining reliable data. As part of the evaluation criteria, we assumed that any commercial system must not be experimental or in developmental stages, but rather that all equipment must have sufficient availability and use so that a performance record has been established. From such a record, engineering/geologic judgment can be applied as to whether the system will successfully provide reliable and useful data.

One important consideration in this study is how effective can the various aquifers be hydraulically isolated from each other in a multiple-completion well. An evaluation criterion for any monitoring system would include a mechanism or mechanisms by which the isolation of each aquifer can be best verified. This quality control may involve the use of acoustic logs, which provide information on cement bond quality, or may involve the measurement of fluid pressures in the borehole above and below the isolated zones. These pressure readings verify that a tight seal has been achieved or may indicate that leakage is occurring from one aquifer to the next.

An important cost and technical consideration for any monitoring system is its simplicity of installation and maintenance. The simpler the monitoring systems, the greater probability that local drillers can be used. This situation will generally lower costs if specialized expertise has to be 
contracted to install complicated equipment. WCC has reviewed general local capabilities and have recommended systems that are relatively simple to install so that local drilling companies might be utilized.

Another design criterion is that the equipment will perform reliably for at least 10 years before maintenance is needed. In some multiple completion well designs, if the downhole monitoring equipment fails, then re-drilling of the well may be necessary. This action would add tremendously to the cost of the monitoring system.

Another major consideration is the mode of taking measurements --can portable manual readout sets be used? or, can the monitoring equipment provide continuous, recorded data at the surface? or, is wireline equipment needed for monitoring individual aquifers? For example, pressure transducers could be installed in each of several aquifers for measuring fluid pressures. These transducers can then be coupled with continuous digital readout and data storage at the land surface. Another example, an installation that involves moveable packers can be used to monitor various perforated intervals one at a time. (This system will be discussed in detail later.) With this equipment, each time an interval is to be measured, the packers must be set and inflated, which would require wireline equipment and a crew of several people. Thus, the cost of individual pressure readings increases due to high labor and equipment costs.

MONITORING TECHNIQUES

PIEZOMETER TYPES

A variety of piezometers have been successfully used in permanent installations to monitor pore-water pressures. 
Based on oral and published reports of other experts and our own experience with a wide variety of piezometers, three types of permanently installed downhole piezometers are generally preferred in practice. These are discussed below along with a portable probe-type piezometer installation that has recently come into use.

\section{Open Standpipe Piezometers}

The simplest type of pore water pressure monitoring installation is a standpipe piezometer (i.e., an open casing of small diameter reaching from ground surface to the subsurface monitoring level). The standpipe casing is usually continuous and unslotted to near the bottom; at that depth, it is hydraulically open to the geologic strata through one or more lengths of slotted or porous-wall casing (walls of filter stone or porous plastic).

A typical arrangement consists of a $38-\mathrm{mm}$ (1-1/2-inch) diameter PVC casing that has 0.01 - to 0.06-inch-wide slots over a casing length of 0.6 to $1.6 \mathrm{~m}(2$ to 5 feet $)$ and standard 1-1/2-inch diameter unslotted PVC casing (cemented or threaded joints) extending up to the ground surface. Figure 1 presents an example of a multiple-cluster installation of standpipe piezometers in an alluvial foundation at the toe of a dam. This type of installation is for depths to about $35 \mathrm{~m}$ (100 feet). For greater depths, the tremie backfill of sand filter around the piezometer intake becomes difficult because there is more opportunity for the sand to bridge and plug inside the tremie pipe. For deeper than $30-m$ (100-foot) depths, pea gravel has been hand-dropped from the surface to provide the filter zones. Generally, the filter zones are longer in length, and the effective depths to each successive filter zone and separating grout seal become less precise as depths increase. 
A variation of the clustered, multiple-standpipe piezometer (such as used in the earth dam example) consists of a single 38-mm (1-1/2-inch) diameter riser pipe section that has a series of hollow-walled couplings with an outer face of porous plastic. Each unit has an attached $10-\mathrm{mm}$ (3/8-inch) nylon standpipe extending to the surface through the $38-\mathrm{mm}$ (1-1/2-inch) standpipe (see Figure 2). This arrangement appears feasible for a moderately deep geothermal emplacement. Grout seals between filter zones might be placed by external grout tubes fixed to the $38-\mathrm{mm}$ (1-1/2-inch) standpipe and extending to near the bottom of each grout zone. The grout seals might be placed by raising, in stages, a single grout tube inside the $38-\mathrm{mm}(1-1 / 2-i n c h)$ standpipe. The grout will be allowed to incrementally fill the casing and to flow through perforated wall sections opposite grout zones, after each filter zone was completed to that height, as shown in Figure 2.

\section{Closed System Piezometers}

Vibrating-Wire Piezometers - This type of piezometer has been used for about 30 years, principally by European engineers, to monitor pore-water pressure in foundations, embankments, tunnels, and hydraulic structures of large dam projects. The instrument has given good performance both during construction and long afterwards during reservoir operations.

A representative vibrating-wire piezometer is shown in Figure 3. The size is approximately $38-\mathrm{mm}$ (1-1/2 inches) in diameter and $305 \mathrm{~mm}$ (12 inches) in length. Pore water enters the piezometer through the porous ceramic filter and acts against a metallic bellows inside the piezometer body. Inside the water-tight bellows, a highly tensioned 
steel wire is stretched from the deformable face of the bellows to its far, rigid end. Pore-water pressure acts to compress the bellows, thereby relaxing the state of tension in the steel wire. A dual, electromagnetic coil system is used for monitoring the natural frequency of the wire. The frequency of vibration is proportional to the tensile stress in the wire. Operation of a batterypowered readout connected to the piezometer by a 12-mm (1/2-inch) diameter shielded cable is used to alternately pluck the steel wire by excitation of one coil and to record the natural frequency of vibration of the steel wire with the other coil. The change in erequency squared of the steel wire is directly proportional to the change in pore-water pressure acting on the bellows.

Advantages of the vibrating-wire piezometer lies in the mode of signal transmission. Frequency signals are a form of digital signal, which is relatively insensitive to changes in electrical properties of the connections and of the cable linking the piezometer with the remote readout point. Moisture on contacts or inside the cable, electrical leakages to ground along the cable, and high electrical noise superimposed on the measurement signal are all phenomena that impair accuracies of other electrical transducer systems. The vibrating-wire system is relatively insensitive to them. The vibrating-wire piezometer can also be made almost insensitive to temperature changes at the piezometer location by controlling the coefficient of thermal expansion of the bellows to the tensioned steel wire. Also, because the signal mode is frequency, cable lengths may be as long as $3 \mathrm{~km}$ ( 1.8 miles) without loss of accuracy. Finally, the total resistance of the coil winding in the vibrating-wire piezometer is sensitive to temperature, and monitoring resistance of these coils can detect temperature changes 
of approximately $1^{\circ} \mathrm{C}$. Incorporating a separate thermistor circuit in the piezometer, as is done by one supplier, will permit reading temperature changes to $0.1^{\circ} \mathrm{C}$.

Pneumatic Piezometers - The other leading closed system piezometer is the pneumatic piezometer. This type of instrument has been favored in the Unites States and has been used successfully in all types of projects for at least 20 years. In its simplest concept, the piezometer body houses a thin, deformable membrane that separates the pore water on one side and an adjustable pressure gas system on the other. The pore water pressure enters the piezometer body through a porous filter and acts to seal the diaphragm against a precision block surface. The ends of gas ports drilled through the block are sealed. The inlet port is connected from the other side of the block by a plastic tube to a remote gas pressure source, and the return port is connected to the same location by a parallel tube (see Figure 4 for a simplified schematic section). Pressured gas, which may be compressed air or, more typically, dry nitrogen, is supplied from the remote reading station at calibrated flow. The operator notes the slowly rising gas pressure on the readout set gage. When the gas pressure equals the pore water pressure, the diaphragm lifts off the block to escape to the return port. The operator then records the maximum pressure from the readout set. This reading, corrected for initial diaphragm inertia pressure and small flow losses, is equal to the pore-water pressure.

In some versions the piezometer body is made of stainless steel, in others, special plastics or fiberglass are used. Some diaphragms are metal, others may be plastic or special elastometers. The sensor components and the associated equipment are simpler in concept than the 
vibrating-wire devices, and horizontal lengths as great as about $610 \mathrm{~m}(2000$ feet $)$ have been used successfully. Generally, however, the pressure heads monitored are only up to $20 \mathrm{~kg} / \mathrm{cm}^{2}$, and higher pressures can pose a problem for plastic tubes and pneumatic operation. One type of equipment requires changing from pneumatic to oil operation for higher pressures, and steel tubing leads are used instead of plastic for higher pressure operation.

\section{Portable Piezometer Probes}

A recent development toward economically and efficiently meeting the needs of monitoring pore-water pressure at several different depths is the use of a portable piezometer probe that operates inside a permanently installed casing. A plastic, $38-\mathrm{mm}(1-1 / 2-\mathrm{inch})$ inside-diameter casing is fitted with a special, ported coupling at each location along the casing length where pore-water pressure monitoring is required. The port is fitted with a spring-loaded; normally closed ball valve. A pneumatic or electric piezometer probe is lowered through the casing on the attached instrument lead, and a locator arm is extended by remote control as the probe approaches a special coupling. The special ported couplings have cam-like landings on their inner surface, which engage the locator arm on the descending probe and rotate the probe into alignment with the coupling valve. This alignment pushes a mating, o-ring sealed, raised surface of the probe against the ball valve, opening it, and allowing the external porewater pressure to be monitored by the electric or pneumatic transducer inside the probe. After measurement, the backing shoe is retracted, allowing the ball valve to close. The locator arm is retracted, and the probe is lowered to the next monitoring coupling (see Figure 5). 
other features of the system include grouted packers between monitoring intervals along the casing, to prevent vertical hydraulic communication of pore waters along the annulus between the casing and the borehole wall. Also available is a special water-quality sampling probe that operates through the same ported couplings.

Although there is interest by industry and the geotechnical profession in the portable probe system, not much published experience is yet available. Until recently, the supplier recommended installation by his own specialist organization. The supplier reported installing a system with 18 monitoring points to a depth of $823 \mathrm{~m} \mathrm{(2700} \mathrm{feet)} \mathrm{below} \mathrm{land} \mathrm{surface} \mathrm{and}$ $841 \mathrm{~m}$ ( 2670 feet) below water table. Available catalog descriptions list a standard probe range of only $305 \mathrm{~m}(1000$ feet) of water depth.

Our judgment at this time is that more published experience with the system is needed before general use can be recommended for geothermal monitoring.

WELL SEALING TECHNIQUES

Grouting

For most multiple-completion installations, a good quality, low-permeability grout seal is inserted between gravel-packed perforated intervals in order to hydraulically isolate one formational unit from the next. Some of the desirable characteristics usually sought for a borehole grout seal are:

1) Low permeability

2) volumetric stability as the grout sets and hardens

3) good bonding with the borehole wall 
4) good pumpability and flowability in grout pipes

5) consistent results when using hardening accelerators.

In order for the grout to be successfully tremied into the borehole, the grout must be pumpable, and it must flow in the tremie pipe. It is important that the grout hydraulically isolate the monitored strata (bounded by the seal) from adjacent strata and restrict the communication of formation fluids through the borehole to any other strata.

As an example, the grout used in 31 multiple-completion wells of an open-pit mine project (Deardoff and others, 1980; shown in Figure 6), consisted of four parts of sand to one part of Portland-type 1-11 cement. Enough water was used to obtain a $10-\mathrm{cm}$ slump consistency. During more than two years of monitoring, only 5 of 75 separate grout seals are believed to have failed. Failure is usually indicated by two separated piezometers giving the same piezometric surface in the multisurface system. Seal failures were attributed to seal placements in major caving and water-producing areas that could not be stabilized with drilling mud.

The grout design was assumed to yield a permeability of about $5 \times 10^{-8} \mathrm{~cm} / \mathrm{sec}$, based on published literature. WCC has run laboratory tests on borehole grouts for sealing boreholes at nuclear waste repositories. Figure 7 gives a tested design and some of the properties for a recommended cement/pozzolan grout. The tested permeability was $1.2 \times 10^{-9} \mathrm{~cm} / \mathrm{sec}$, a very low-permeability grout. Testing of this grout showed good bonding with the rock wall, even when the wall was covered with drilling mud residue. 
Permeable Grouted Seals - A most interesting study by Vaughan (1969) suggests that, for a typical multiple installation, the permeability of a borehole plug is not too critical. In fact, the permeability of the grout can be significantly greater than the permeability of the permeable strata being monitored, without the introduction of significant error in the pressure data.

For a piezometer to successfully record fluid pressure changes over a wide range of pressures, errors in piezometer readings may be small. Figure 8 shows the piezometer error for a particular geometry of piezometer installation, with a variable or constant head pore-water pressure acting over the length of the plug. Piezometer error is plotted with respect to a correct pressure of water in the monitored strata. Error data are plotted for three different ratios of plug grout permeability to ground permeability, (i.e., 10, 500 and infinite). The data show insignificant error for all ratios where the pressure in the monitored strata is in equilibrium with the ground-water system in the immediately adjacent ground (an impervious boundary is assumed to separate the top of the monitored strata from the adjacent ground, except through the grout plug). The source of error is seepage through the length of plug--a gain of water from remote strata to an underpressured piezometer zone, or loss of water to remote strata from an overpressured piezometer zone. Consequently, where the monitored strata pressure are not in equilibrium with the surrounding ground, errors in the piezometer reading can occur for various grout permeabilities, as shown in Figure 8 . The error is probably insignificant for most types of installations if the permeabilty of the grout is only about one order of magnitude greater than the formation. 
It can be shown that the error in permeability for a given plug is a function of the installation geometry. The error in the piezometer reading is reduced if the length of the piezometer is increased. This effect is shown for a sample installation in Figure $8(b)$.

If the permeability of the grout can be assured to be low, but the contact and condition of the borehole wall is disturbed (i.e., due to caving as in the open-pit mine project), potential magnitudes of error can be examined by assuming an annulus of relatively high permeability and making the calculation proposed by Vaughan (1969).

In installations where changes in the quality of the formation waters is also important, the permeability of the grout seals must be as low as possible to prevent quality changes to migrate through the seal.

\section{Filter Zones}

Filter zones are needed in standpipe piezometers (i.e., borehole casing with slotted or porous bottom intake sections) if in-situ permeability tests are planned in the strata to be monitored. These tests are usually conducted by changing the equilibrium head of water in the standpipe (artificially raising or lowering the static water level) and measuring the incremental recovery of equilibrium head with time (rising head or falling head test analysis). Measurements of possible changes in ground permeability with time might be needed for permeable strata closest to points of injection of geothermal waters. For example, the permeability of such strata could be influenced by thermal plumes or precipitates from the injection water. A filter zone is also needed if a standpipe piezometer or a combined diaphragm piezometer/water-sampler 
unit is installed in the borehole for the dual purpose of measuring pore-water pressure and obtaining water-quality testing samples, as discussed later.

An example of a situation where a filter zone is not needed but is almost always used, is the case where only subsurface pore-water pressure monitoring is required. The state-of-thepractice is to use filter zones around such a piezometer, as shown in Figure 9. However, this method involves difficult and expensive installation and, according to Vaughn (1969), may not be neccessary for most installations where only porewater pressure monitoring is needed. Even the practice of drilling piezometer boreholes without the use of bentonitebased drilling muds, using instead more expensive organic drilling fluid that reverts to water after drilling, is unnecessary in most such cases. This can be demonstrated for monitoring of the piezometric head of some discrete strata below ground surface, using a standpipe piezometer installed in a grout-filled borehole. The response time of a long cylindrical piezometer can be estimated for two-dimensional radial flow if it is assumed that the grout and soil in which the piezometer is placed are incompressible (Vaughan, 1969).

Figure $8(c)$ shows response time calculated for a piezometer cylinder that is $3 \mathrm{~m}$ (10 feet) long and $57 \mathrm{~mm}(2-1 / 4$ inches) in diameter and is placed in grout of permeability $\mathrm{kg}$ of either $10^{-6} \mathrm{~cm} / \mathrm{sec}$ or $10^{-7} \mathrm{~cm} / \mathrm{sec}$ into a borehole of $89 \mathrm{~mm}$ (3$1 / 2$ inches) in diameter or $20 \mathrm{~cm}$ ( 8 inches) in diameter. The response times are compared for different soil permeabilities with the response time of a piezometer with a sand filter of similar radius. When the permeability of the grout is greater than that of the ground, the response time of the piezometer in grout is only slightly greater than that of the piezometer with the sand filter. When the ground has a permeability more than two orders of magnitude greater than the grout 
permeability, the response time is controlled by the grout annulus only. For most engineering purposes, the response times of the piezometers in grout are adequate for all permeabilities of the ground (Vaughan, 1969).

\section{PERMANENT INSTALLATIONS}

This section of the report will discuss available options for installation in boreholes of a permanent sensor apparatus that is suitable for measurement of pore-water pressure, temperature, and water quality. Permanent sensors may be connected to data acquisition systems that will continuously monitor and store data and may be coupled with economical microcomputers to permit a wide range of data reduction and presentation possibilities. Alternately, permanent sensors can be periodically monitored with portable readouts, usually by a single individual, and the data can be recorded manually. or, if semi-automtic readouts are used, the data can be input directly to and stored on tape cassettes or punchtapes for later processing.

Initial installation costs of permanent sensor apparatus may or may not be more expensive than systems featuring portable sensors that traverse the depth to be monitored and that are moved from one borehole to another. As a general rule, monitoring costs are usually less for permanent installations because they can be automated or read by one person in a comparatively short time. Based on WCC's experience in geotechnical instrumentation, once a permanent sensor is successfully installed, the data are generally more reliable over time than that of portable sensors. When the permanent sensor fails, the failure is usually obvious, whereas the 
portable probe is more subject to operator techniques, variable downhole traverse conditions, rough handling, and greater variability in calibration functions.

In cases where it is desired to monitor hydrogeologic parameters at different depths, a decision needs to be made whether to install more than one permanet sensor in a single hole. If four monitoring levels are needed down to a total depth of $30 \mathrm{~m}$ ( 100 feet), there may not be much of a cost difference between all sensors going in one hole or each sensor going in a separate hole down to its design depth. The resaon is that the cost of multiple holes may be offset by the care and labor usually needed to construct special backfill sections in the multiple-sensor borehole. Also, each sensor has to be correctly positioned and coupled to each geologic unit that is to be monitored. Extra care must be taken to isolate adjacent sensors and strata from each other. However, there may be considerable cost savings in placing mutiple sensors in a single borehole to depths of 330 $\mathrm{m}$ (1000 feet) or more, due to the comparatively high costs of drilling to such depths. The cost can be far more than the cost of additional time to construct special backfill sections in the multiple-sensor borehole.

The only reservation typically expressed about using the multiple sensors (also called multiple-completion wells) concerns the level of confidence in being able to effectively place the zoned intervals of special backfill in the borehole so that the sensors are in communication with the strata that are to be monitored. At the same time, the sensors must be effectively prevented from communicating through the borehole with any other sensors or strata. In fact, the same general problem exists for the single sensor installation: the sensor and the strata to be monitored must not communicate through the borehole with any higher strata. The resolution of this 
problem is simplified because once the grout backfill operation is started, it may be continued to ground surface. Because grouting one sensor is similar to one stage of the multiple-completion wells, only multiple-completion is discussed here for illustration of the problems and the means of solution. 
MULTIPLE-COMPLETION WELLS

Shown on Figure 9 are details of a typical multiple-completion well at a deep, open-pit mine that is comprised of four piezometer installations to a depth of $206 \mathrm{~m}$ (675 feet) (Deardoff and others, 1980). This detail is representative of many multiple-completion wells. The sensor is typically between $2.54 \mathrm{~cm}$ ( 1 inch) and $5.08 \mathrm{~cm}$ ( 2 inches) in diameter and up to about $15.24 \mathrm{~cm}$ ( 6 inches) in length. Hydraulic or pneumatic piezometers are each connected to the ground surface by 2 to 4 tubes of approximately $5 \mathrm{~mm}(0.2$ inch) diameter each, separate or enclosed in a single sheath. Electric piezometers have 2 to 5 conductors in a single-sheathed, multi-conductor cable.

The filter zone around each piezometer is usually composed of a very permeable sand or fine pea gravel. The use of pea gravel is best in deep holes because of the difficulty of placing sand in deep, water-filled holes without bridging in the hole or plugging sand injection pipes. Pea gravel can be carefully hand-dropped from the surface while circulating fluid in the hole, and the gravel will settle into place at the bottom of the hole in a short time.

The entire filter zone for a piezometer in typical shallow hole installations may only be $1 / 2$ to $1 \mathrm{~m}(1.6$ to 3.3 feet) in length. Approximately one-quarter of the zone is placed initially; the piezometer is then lowered in place, and the remaining filter zone is placed around and above the piezometer. Frequently, the top surface is tamped to provide a good base for the seal zone.

Installations at deep depths are generally less concerned with the performance of discrete, thin geologic strata. The filter zone, both for practical installation purposes and monitoring needs, can be on the order of 3 to $6 \mathrm{~m}$ (10 to 20 feet) in 
length. Because of the length of such a filter, it is not necessary to tamp the top surface to prevent intrusion of a grouted sealing plug. Grout intrusion into the filter should be less than perhaps 0.1 to $0.5 \mathrm{~m}$ ( 0.33 to 1.6 feet) for a pumpable grout.

The grout seal itself is a key element in a successful multiple-completion well. A detailed discussion of grout technology applied to installation of downhole sensors in mutiple-completion wells was discussed earlier.

\section{COMBINED INJECTION WELL AND MONITORING INSTALLATIONS}

The use of injection wells is a common feature in almost all geothermal production plans because of the need to dispose of poor-quality spent fluids without releasing them to surface waters. The common practice of injecting poor-quality geothermal fluids into subsurface strata is one of the principal reasons for ground-water monitoring. Such monitoring will alert of potential impairment to contiguous ground-water supplies as a result of the injection. For purposes of discussion in this report, it has been assumed that injection would take place at depths of approximately 1219 in (4000 feet), while ground-water monitoring efforts would be limited to depths above $457 \mathrm{~m}$ (1500 feet).

There is a potential for decreasing the cost of installing the necessary instrumentation for monitoring ground-water impacts, if these instruments can be installed in the same drill hole as the injection well casing. The possible use of the injection well borehole for the installation of the groundwater monitoring instruments has advantages and disadvantages. The most obvious advantage is the savings in cost over having to drill a separate hole for installing instruments. This savings may be offset by the extra time and expense 
needed to install the injection casing along with whatever monitoring instruments are required. Potential disadvantages may be: 1) the need for higher quality grout seals above the injection depth to guard against communication with shallow aquifers along the injection casing; and 2) localized thermal effects that may decrease instrument accuracies and accelerate corrosion or material failure of any susceptible instruments or instrument leads.

As an example, the $10.2-\mathrm{cm}$ (4-inch) diameter injection fluid casing instrument types considered in previous discussions could be sized to fit in the annulus of a standard $20-\mathrm{cm}$ (8inch) nominal size drill hole. If the instrument type were a standpipe piezometer, the riser pipe might be attached to the injection casing as it was being fabricated and lowered into the drill hole. A $13-\mathrm{mm}$ (1/2-inch) stainless steel tube riser might be used for single point, pressure-monitoring standpipes, and up to perhaps $5 \mathrm{~cm}(2$ inches) for multi-point or sampling standpipes. Casing centralizers (or offsets) that would provide at least $25 \mathrm{~mm}$ ( 1 inch) of clearance of both injection well and standpipe from the drill hole wall would be needed to ensure adequate grout encasement during cementing operations. Electrical or pneumatic piezometers, with or without sampling accessories, could also be installed. As the casing is installed, the required electrical or pneumatic connection leads and sampling tubes could be routed beneath angle-iron strips, with the strips tack welded or mechanically strapped to the injection pipe, depending on corrosion potential.

Temperature-resistant instrumentation might also be run inside the injection casing. For example, a small-diameter standpipe could be run inside the injection casing from a filter-covered 
piezoneter port drilled through the casing at depth and could be accessible to a depth-measuring probe outside the well head, at surface.

The upper $457 \mathrm{~m}$ (1500 feet) of injection pipe might also be double-walled casing, allowing a number of small-diameter instrument leads or risers to be used to different depths, without the problems of flow friction, scaling, and corrosion associated with exposed internal leads or riser pipes. The cost of such casing would be substantial, however.

In conclusion, the technical possibilities of combining instrumentation with injection well installations do exist. However, the cost savings of not drilling a separate hole may be completely offset by other costs and data uncertainties, such as excess pressure gradients from the high-pressure injection point extending up along any disturbance zones caused by drilling or along the grout/soil interface. Another difficulty is that temperature change could not be used as a monitoring parameter for detecting migration of injected fluids toward the shallow, monitored aquifers because of the constant, heated environment around the drill hole created by the injection casing.

WATER-QUALITY SAMPLING

In addition to the monitoring of pressure changes, waterquality monitoring may be necessary in order to evaluate potential impacts of geothermal production and injection. Cost of water sampling might be minimized by combining the downhole water-sampling and the pressure-monitoring instrumentation in the same well. The first water-sampling requirement is for a filter zone at the monitoring depth. Consequently, fully grouted well installation techniques, suitable for piezometers alone, are not satisfactory for a 
combined water-sampling/pressure-monitoring installation. The water-sampling task is most easily combined with a single standpipe piezometer installation, since water sampling can be performed by lowering a mechanical actuated sampler through the standpipe or by pumping the zone, using small, submersible electric pumps or airlift techniques.

For multiple-completion wells, the requirements become more complex; however, new developments and available techniques have potential. Some published experience is needed to evaluate their performance. The principal features of a few of these selected techniques are discussed below. Figure 10 (a) and (b) are schematics of relatively simple airlift samplers, the only difference between the two being the intake features. The collection tube of these samplers could serve as small bore standpipe piezometers for pressure measurement, or the units could be placed in the same filter zone as a closed system piezometer. Figure $10(\mathrm{c})$ shows an airlift sampler combined with a closed-system piezometer, a pneumatic type in this case, and connected to surface by a multi-tube, single sheath lead. Figure $10(d)$ shows a schematic of an airlift sampler combined with one of the intake units of a multiple-unit standpipe piezometer.

The commercial airlift units are primarily designed for depths of $67 \mathrm{~m}(200$ feet) at most. However, although the manufacturer of the instrument illustrated in Figure $10(\mathrm{c})$ makes a standard version for 43-m (140-foot) water depths, a special version is available for $915-\mathrm{m}$ (3000-foot) depths (oceanography applications). Because the gas pressure necessary to lift $915 \mathrm{~m}(3000 \mathrm{feet})$ of water is quite high $\left[91.5 \mathrm{~kg} / \mathrm{cm}^{2}(1300 \mathrm{psi})\right]$, special materials are needed for tubing (stainless steel) and for sampler components. 
PETROLEUM INDUSTRY TECHNIQUES

Many different combinations of oil-field completion equipment are potentially applicable to monitor geothermal systems in the Basin and Range province. External and internal casing packers, which are installed with various grouting techniques and tubing strings, are commonly used to isolate multiple zones in oil-and gas-producing wells. To monitor test zones that have been selectively completed, various wirelineactuated tools are available to open and close valves downhole and to lower water-sampling or pressure-monitoring devices. of all the possible combinations, one design has the greatest advantages for this particular geothermal monitoring application.

This preferred design incorporates oil-field technology for the deeper zones but uses standard soils engineering/hydrology techniques for monitoring the shallow zones (Figure 11). At the bottom of the well, the injection zone is left uncased. The 20-cm $(8-i n c h)$ casing extends to just below the lowermost monitoring zone, approximately $457 \mathrm{~m}(1500$ feet). Grout is injected into the annulus from below the bottom casing shoe and extends upward to the two lower monitoring zones, which are selectively isolated by inflatable external casing packers. Two sets of these packers would be installed with the casing string and expanded to seal against the borehole wall prior to injecting the cement. An internal cement bypass allows the cement to flow upward through the zone without contacting the formation face of the borehole. sliding-sleeve valves are positioned within each of these two zones in order to establish flow connections. These valves may be opened and closed downhole in the well by using a wireline device. A dual-completion hydraulic casing packer system would be lowered inside the casing on 9-cm (3-1/2-inch) tubing in order to isolate this lower monitoring zone from the injection zone 
below. Access for monitoring the zone would be provided by a $2.5-\mathrm{cm}(1-\mathrm{inch})$ riser pipe connected to the upper dual completion packer. The second monitored zone from the bottom would lie above this packer and would be monitored using a $2.5-\mathrm{cm}(1-i n c h)$ tubing set inside the casing. The two shallow monitoring zones would be isolated outside the casing using a sand packer, bentonite and grout $2.5-\mathrm{cm}(1-\mathrm{inch}) \mathrm{riser}$ tubings set outside the casing in the annulus.

Even though this system has a great deal of flexibility and many technical merits that would probably yield excellent data and moderate operating costs, the initial installation costs are relatively high compared to the costs of drilling separate monitoring wells to each zone. A cost estimate of the completion system is provided in Table 1. This estimate assumes that the costs of drilling a 1219-m (4000-foot) injection well and completing it with $610 \mathrm{~m}$ (2000 feet) of 22$\mathrm{cm}$ (8-5/8-inch) casing, Item 10 of Table 1 , are covered as part of a standard geothermal well completion.

SURVEY OF PRACTICE IN MONITORING MULTI-LAYERED AQUIFER SYSTEMS

To obtain a more comprehensive background on present monitoring practices, a systematic survey has been made of 30 knowledgeable scientists and engineers. In addition, numerous reports and instrumentation brochures have been reviewed. The results of this survey are most significant, as summarized in the discussion that follows.

Although many types of instrumentation systems are used in the ground-water industry to monitor fluid conditions in mines, dams, landfills, and small-scale test plots, it is noteworthy that two principal types of installations are used to monitor most multi-layered aquifer systems in the country. These include: 
(1) Existing water wells that have been drilled for water supply. They are measured either manually or with continuous recorders. Generally, these wells have been selected only because they are available. The principal problems in using these wells are that they frequently are not of the desired location or depth, and they usually are perforated in wide depth intervals, thus registering composite water levels.

(2) Specially drilled standpipe piezometers, constructed for either a single piezometer or a cluster of two to eight separate piezometers of different depths in a single drilled well.

Three federal organizations--the U.S. Bureau of Reclamation, the U.S. Geological Survey, and the U.S. Army Corps of Engineers--have made widespread use of multiple-completion installations. Most other organizations have used single piezometer installations. The dominant reasons for preferring single-completion installations reportedly are: (1) single completions avoid numerous complications and, in the long run, may be less expensive, particularly at shallow depths; (2) the possibility of getting a reliable water seal between piezometers in the borehole and thereby reliable water data is more certain in a single installation; and (3) if something goes wrong with a multi-piezometer system, either during the drilling or years later, the entire installation may be fouled, and little remedial action can be taken.

In conducting a survey of ground-water experts, our concern was with the design and use of multiple-completion systems. Few questions were asked regarding the use of other types of systems. Several experts of the U.S. Bureau of Reclamation 
and the U.S. Geological Survey have been responsible for the design and construction of multiple-completion installations at numerous sites during the past 30 years.

In the following summary, the names and responses of contacts in the three federal agencies are listed first, followed by a listing of representatives of other organizations and their responses.

\section{Organizations Using Multiple-Completion Wells}

U.S. Bureau of Reclamation

1. William Cook Sacramento, CA

(916) 484-4228
Multiple-completion piezometers have been used in California for many years. Most were constructed in the $1950^{\prime}$ 's and 1960's and consisted of clusters of 3 or 4 standpipe piezometers of varying depths in a single uncased borehole. Piezometers are generally $25 \mathrm{~mm}$ (1-inch) galvanized iron pipe, with a short screened section on bottom. Standpipes are individually lowered in an open hole, starting at the bottom. Gravel is placed opposite each perforated interval, and placter cement grout is injected in the intervals between. These systems have proved quite successful, if carefully 
installed, and are recommended for all types of applications.

2. Herb Ham Denver, CO (303) 234-6343
3. Dick Raymond Phoenix, AR (602) 261-3188
Multiple-piezometer installations have been used for many years in 6 or 8 western states under a wide diversity of field conditions. Designs are cluster of 3 or 4 standpipes in a single uncased borehole, similar to that described by W. Cook (above). Singlepiezometer completions are preferred, especially for shallow depths. Uncertainties always remain with multiple completions. If carefully constructed, multiple completions are still used and are recommended for most applications. Today, because of diverse field applications and high drilling costs, final design of each installation is left to local engineers.

Probably two dozen multiplecompletion installation in uncased wells have been completed in central Arizona during the past 5 years. 
Installations are similar to that described by w. Cook (above). Usually 2 standpipes are placed in each uncased well; galvanized pipe is always used. Few problems have been encountered, and satisfactory results are being obtained. Recommends multiple-piezometer installations.

\author{
U.S. Geological Survey \\ 1. Francis Riley \\ Clusters of seven standpipe \\ Denver, CO \\ (303 234-2700 \\ piezeometers of varying depths \\ in a single uncased well at \\ one site and eight standpipes \\ in another were successfully \\ monitored for many years in \\ the San Joaquin Valley, \\ California. Standpipes were \\ $3.8 \mathrm{~cm}(1-1 / 2-$ inches $)$, with a \\ screened section on bottom; \\ installation was as described \\ by w. Cook (above). Great \\ care was required to have \\ gravel and grout properly \\ placed. \\ Technique recommended for \\ future installations. Some \\ uncertainties always remain. \\ Single holes preferred at \\ shallow depths.
}


2. Ben E. Lofgren

San Francisco, CA

\section{(415) 956-7070}

3. Ron Page

Sacramento, CA

(916) 484-4666

4. C.D. Whiteman, Jr.

George Cardwell

Baton Rouge, LA

(504) 389-0442 as above

Three deep, uncased multiplecompletion wells were recently installed in the Sacramento valley, each with three $10-\mathrm{cm}$ (4-inch) standpipe piezometers. A $1.5-\mathrm{m}$ (5-foot) screened interval was at the bottom of each piezometer. Wells were completed with grout seal above and below each screen, but no gravel was used. Continuous records for 1 year indicate good waterlevel data.

Most monitoring in Baton Rouge area is accomplished with single-completion wells. Several multiple installations have been constructed, using a deep 6.5-cm (2-1/2-inch) standpipe installed inside a shallower 10-cm (4-inch) standpipe. Both pipes have a screened section on bottom. The 6.5-cm (2-1/2-inch) pipe measures deep water levels, while the 10-cm (4-inch) pipe monitors the shallow water levels. A commercial packer separates the two zones. 
Single completions are preferred throughout the Gulf Coast.

5. Jack Hickey Tampa, FL (813) 228-2124

6. Julian Soren Long Island, NY (516) $938-8830$
Many multiple-completion wells are in operation in Florida. Most have four small-diameter standpipes of varying depths per well, with proper grout seals separating the various depth zones. In most instances, about $61 \mathrm{~m}(200$ feet) of well casing is set through the upper alluvial sequence, then openhole through limestones. No one is entirely happy with multiple completions. A state groundwater committee has recently recommended that no more multiple-completion monitoring wells be permitted.

About 12 multiple-completion wells were installed on Long Island during 1950-60's. Most had two to four open standpipe piezometers that have a stainless steel screen on the bottom in each uncased well. Gravel is installed around each screened section, with grout above and below. No other types of multiple installations are known in the 
area, and these are all now

more than 15 years old.

Everyone prefers singlecompletion wells, and costs are probably no greater than multiple completions. Few of these old multiple installations are still in operation.

U.S. Corps of Engineers

1. Frank McLean

Extensive use has been made of San Francisco, CA both open and closed system (415) 556-4705 piezometers, principally in dam and damsite investigations. Depths usually range from 30 to $50 \mathrm{~m}$ (98 to 165 feet). Clusters of standpipe piezometers are less complicated and less expensive and probably more commonly used. Closed-system nitrogen pneumatic systems are less reliable and require frequent calibration. Refer to Corps of Engineers manual EM 1110-21908, Part 1 for design details.

2. Greg Spencer Omaha, NE (402) 221-7342

Same as above. Experience has shown that open-system standpipe piezometers, in clusters of two to four, are generally most effective, if 
the installation is in permeable sands or gravels. Closed pneumatic systems are preferred if the installation is in impermeable interbeds or tight fill materials.

Other Multiple-Completion Users

1. Ray Wyche

Pecos Valley

Conservancy District Roswell, NM (505) $622-700$
Two multiple-completion wells were installed many years ago, each with three standpipes, to monitor three distinct artesian zones. These were concentric wells--one inside the other-with the deepest being the smallest diameter. Early records were good. Now all three zones are comingled.

2. EPA Procedural Manual Suggests use of either: For Ground-Water (1) cluster of standpipe Monitoring, 1977 monometers in single well, or (2) a number of singlecompletion wells clustered in close proximity.

3. Paper mill near Eva Dell, TX. Reported by Bob Gabrysch (USGS)
Several depth zones of an aquifer system are monitored by a series of three wells of decreasing diameter (one drilled inside the next, with the smallest well monitoring the greatest depth). Data 
were never good. Installation was made a long time ago by William Guyton, Sr.

4. William Black

The Westbay monitoring

Westbay Instruments, equipment is capable of Ltd., West Vancouver, BC, Canada measuring many different depths with a single, (604) 926-8541 specially instrumented well. This equipment is especially useful at shallow depths, particularly in contamination and landfill investigations. Present equipment uses PVC pipe and rubber packers. Company is considering the design of stainless steel equipment with high-temperature packers for use in deeper, high-temperature environmental studies.

\section{Other Experts Contacted}

Each furnished background information and follow-up leads but had no direct involvement in multiple-completion installations.

1. Bob Gabrysch, U.S. Geological Survey, Houston, TX 
2. John Bredehoeft, U.S. Geological Survey, Menlo Park, CA

3. Roger Wolff, U.S. Geological Survey, Reston, VA

4. A. Ivan Johnson, Woodward-Clyde Consultants, Denver, $C O$

5. T.N. Narisimon; Lawrence Berkeley Láboratory, Berkeley, CA

6. Norman Goldstein, Lawrence Berkeley Laboratory, Berkeley, CA

7. Ron Schroder, Consultant, Berkeley, CA

8. Helen Joyce Peters, California Department of Water Resources, Sacramento, CA

9. Charles Flagg, US Bureau of Reclamation, Denver, CO

As far as known, multiple-completion wells of varying depths, as described above, have not been used in areas of geothermal development. Ben E. Lofgren, retired, U.S. Geological Survey, has installed multiple-completion wells in three geothermal areas in which both extensometers and fluid-monitoring instrumentation are operating in a single-cased we11. These instruments, however, recorded conditions at only one depth--the bottom of the well. We see no reason why clustered multiple-standpipe piezometers, as described above, cannot be used in multiple-aquifer systems overlying geothermal systems. This type of multiple-completion installation certainly should be included in the alternative designs considered at any geothermal site.

\section{Drilling Costs}

The drilling of monitoring wells can be an expensive undertaking, especially if large-diameter boreholes are required to serve as multiple-completion wells. It was found in this study that the cost of drilling a $61-\mathrm{cm}$ (24-inch) 
diameter well is approximately four to five times the cost of drilling a 20-cm (8-inch) -diameter well to a depth of $457 \mathrm{~m}$ ( 1500 feet). The principal reason for this significant cost increase is that a standard water well drilling rig can complete an 20-cm (8-inch) borehole to $457 \mathrm{~m}$ (1500 feet), whereas it requires a large, specially designed rig to arill a $61-\mathrm{cm}$ (24-inch) well to $457 \mathrm{~m}$ (1500 feet). Such equipment is available in the oil industry, but the cost makes it impractical for use in the present study.

The cost of drilling and completing four individual monitoring wells, using the established criteria, varies between $\$ 24$ and $\$ 50$ per $30 \mathrm{~cm}$ ( 1 foot) of drilling. The large variation is primarily due to the mobilization costs, which can be reduced by selecting drilling contractors who are located near the geothermal site.

\section{CONCLUSIONS AND RECOMMENDATIONS}

In considering the use of clustered standpipe piezometers, three limitations must be considered in the design selection:

(1) Open standpipes cannot be used where fluid-pressure heads extend above land surface or where thermal waters have a tendency to "flash" on rising.

(2) Volatile constituents in the formation waters may be lost in sampling open-piezometer systems. Thus, water-quality analyses may be non-representative.

(3) Because of the special conditions that generally prevail around a geothermal injection well (such as heavy-duty casing and valving, heavy drilling muds in the completed borehole, heated thermal environment, and frequent access into the well by large equipment), the installation of clustered standpipe piezometers in the annulus of the injection-well 
borehole is probably not acceptable. The cost and security of drilling an independent nearby monitoring well will probably prove to be warranted in most geothermal settings.

Woodward-clyde consultants has determined that it is impractical to recommend a generic "most suitable" monitoring system design that is best for all situations. The principal reasons for this difficulty are diversity of field conditions and drilling costs. WCC has found that costs vary tremendously even in the Basin and Range province. The U.S. Bureau of Reclamation has confronted this same problem, and they generally give their local offices the authority to decide whether to construct single- or multiple-completion wells for a given project. Other variables that will impact the design selection are: the availability of equipment, depths of drilling, and geologic conditions encountered in drilling.

Based on those considerations, WCC recommends three monitoring well designs for general use in monitoring ground water at geothermal sites. These designs are schematically represented in Figure 12. Based on our surveys in this study and on our professional judgment, a single-standpipe piezometer is considered the most cost-effective monitoring technique for depths less than $152 \mathrm{~m}$ (500 feet). Below $152 \mathrm{~m}$ (500 feet) and depending on site conditions, any of the three systems (Figure 12) may prove best suited for those conditions.

\section{SINGLE-STANDPIPE PIEZOMETER DESIGN}

This design is probably best for most shallow monitoring needs and, at some difficult stratigraphy locations, it may even be best for moderate depth monitoring. The single-standpipe piezometer becomes less cost effective as the monitoring depths increase and probably is not justified below $\overline{640} \mathrm{~m}$ 
( 2100 feet). For depths between 152 and $640 \mathrm{~m}$, the singlestandpipe piezometer may be a viable design if local drilling costs are reasonable. Where water-quality monitoring is important and if heavy drilling muds are needed for hole stability, then the single-standpipe piezometer is recommended for all depths because well development can be better a complished.

\section{MULTIPLE-STANDPIPE PIEZOMETER DESIGN}

This type of design will probably be most cost effective for monitoring multiple aquifers at moderate to deep depths, where fairly large drill rigs are needed for difficult drilling conditions. The same rigs can then more easily handle multiple-pipe installations. The multiple-standpipe piezometer monitoring system, depicted in Figure 12(b), can be used in mudded holes where mud contamination of the borehole is not great. This type of monitoring system would involve drilling a 20 - to $28-\mathrm{cm}(8-$ to 11 -inch) borehole. The standpipes would be $4-\mathrm{cm}(1-1 / 2-i n c h)$ I.D. iron pipes having a short intake length of well screen on the end. These piezometers may be assembled on the surface with spacers to prevent touching downhole.

\section{CLOSED-SYSTEM PIEZOMETER DESIGN}

This type of design will probably be best suited where drilling conditions are difficult, where permeabilities are very low, and where the hydrogeology of the system tends to be complex, requiring more monitoring points at moderate to deep depths. The closed piezometer, which has water-quality sampling capability [Figure 12(c)] should be used only in boreholes that have been drilled with a degradable organic mud or a foam mud. A suitable drilling mud program should be developed by one of the service companies that supply drilling muds. This service is usually free. Special consideration of 
mud is needed because: I) the typical airlift samplers would be relatively ineffective in strata plugged by mineral muds, 2) there is no opportunity for well development, and 3) a drilling fluid that will not lead to excessive contamination of water-quality samples is needed. Organic muds are substantially more expensive than mineral muds (i.e. bentonite); however, the piezometers are much cheaper than the cost of riser pipes for open standpipe sampling. The closed piezometers would be installed in a $20-\mathrm{cm}$ ( 8 -inch) borehole drilled to a 457-m (1500-foot) depth. The closed piezometer shown in Figure $12 \mathrm{c}$ requires the supervision of an expert who has installed such equipment. Options $a$ and $b$ in Figure 12 could be handled by local expertise.

OTHER RECOMMENDATIONS

We recommend that aquifer-monitoring equipment not be installed in the same drill hole as the injection well. The savings in cost of not drilling a separate hole for the monitoring may be completely offset by other costs and data uncertainties. These factors are explained in more detail in the report.

Also, we recommend that the portable piezometer probe not be used until more published experience with the system is available. 
U.S. Army Corps of Engineers, 1979, Operation Manual EM1110-21908, Part 1 .

Deardorff, G.B., Lumsden, A.M., and Hefferon, W.M., 1980, "Pneumatic Piezometers: Multiple and Single Installations in Vertical and Inclined Boreholes," National Research Council of Canada.

Vaughan, P.R., 1969, "A Note on Sealing Piezometers in Boreholes," Geotechnique, v. 19, no. 3, pp. 405-413.

Westbay Instruments Ltd., 1981, Technical data and company background, West Vancouver, B.C., Canada. 
TABLE 1

COST ESTIMATE OF COMPLETION SYSTEM

$\underline{\text { Item }}$

Estimated Cost

1. Well head for dual tubing string

$\$ 40,000$

2. 9-cm (3-1/2-inch) tubing for injection $\$ 15,000$ string 2000 feet at $\$ 7.50 /$ foot

3. Four external casing packers

$\$ 15,700$

$[22 \mathrm{~cm}(8-5 / 8$ inches $)] \$ 3,925$ each

4. Four sliding sleeve valves

$\$ 8,200$

$[22 \mathrm{~cm}(8-5 / 8$ inches $)] \quad \$ 2,080$ each

5. Four $3.05 \mathrm{~m}(10-\mathrm{foot})$ bypass extensions

$\$ 11,100$

$[22 \mathrm{~cm}(8-5 / 8$ inches $)$ I.D.] $\$ 2,775$ each

6. One cement stage tool $[22 \mathrm{~cm}(8-5 / 8$

$\$ 3,000$

inches) I.D.]

7. Technician charges for installation

$\$ 4,500$

(includes transportation and subsistance)

8. 2.54-cm (1-inch) tubing or riser pipe

$\$ 2,800$ $869 \mathrm{~m} .(2850$ feet $)$ at $\$ 1.00 / 0.3 \mathrm{~m}$

9. Four days rig time at $\$ 2,400 /$ day $\$ 9,600$

10. Drilling and completing
$\begin{gathered}4000 \text {-foot well } \\ \text { Total: }\end{gathered}$$\frac{\$ 475,000}{\$ 585,000}$ 
NOTE: For sand backfill, hand place well-graded sand through large funne into tremie pipe while continuously washing down through funnel with water hose. Withdraw tremie as sand level rises. Check levels by sounding.

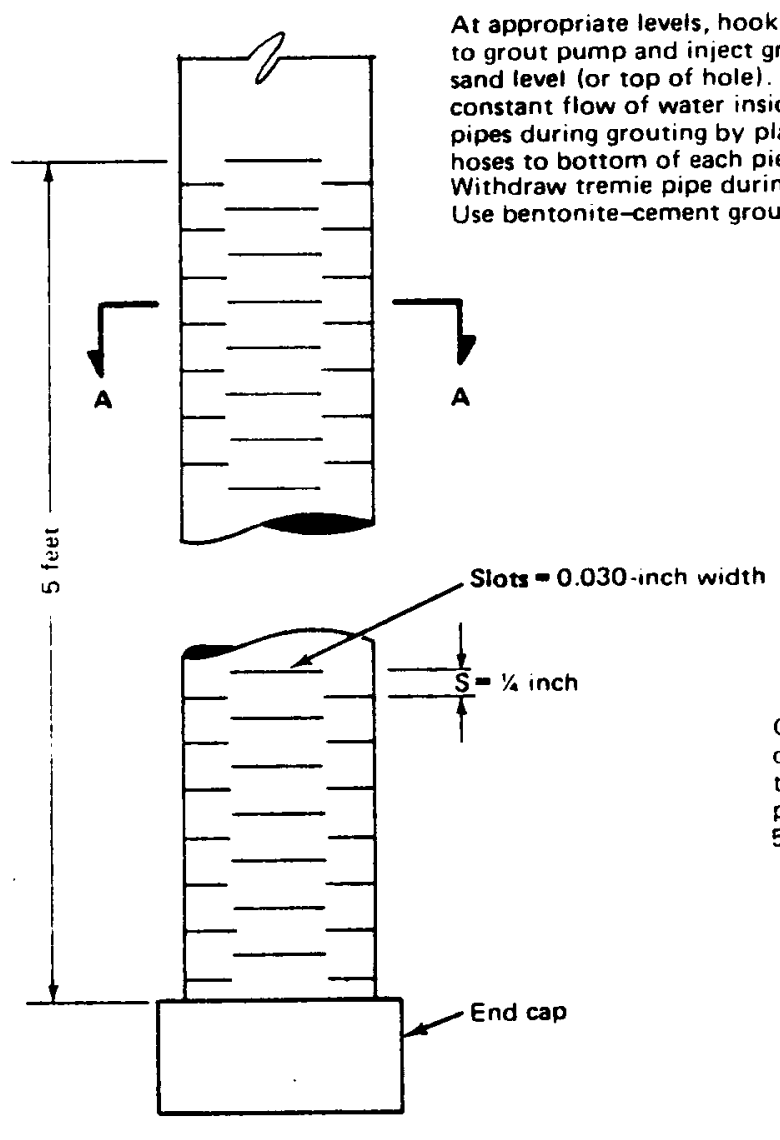

2-inch diameter pipe
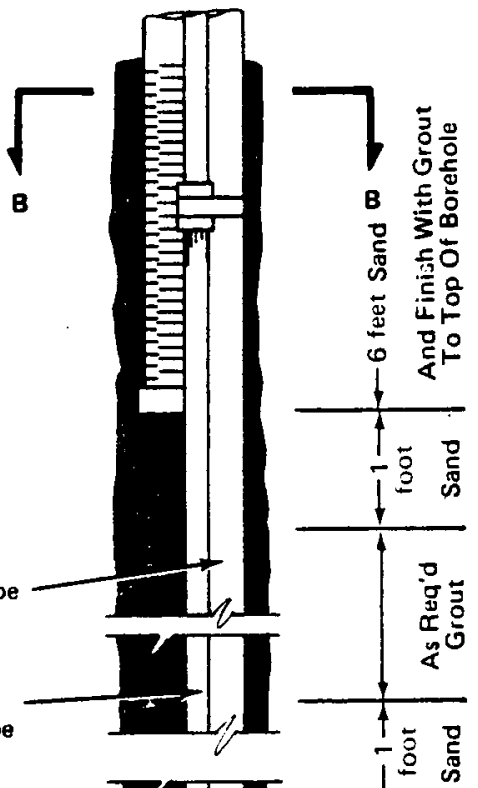
plastic tremie pipe

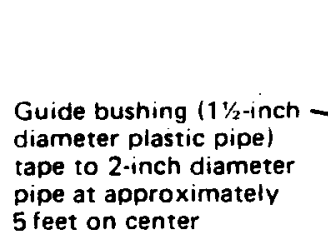
5 feet on center

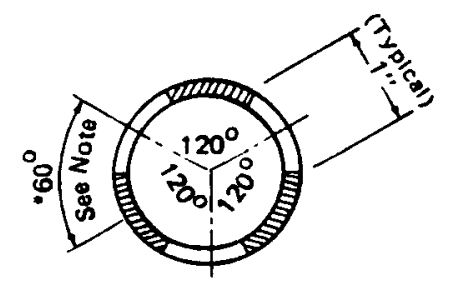

SECTION A-A

- NOTE: Rotates lot pattern 60 degrees for each vertical spacing increment of $1 / 2$ inch.
1 -inch diameter
tremie pipe. Use 2 tremies as shown for lengths of boreholes with

2 piezometer pipes

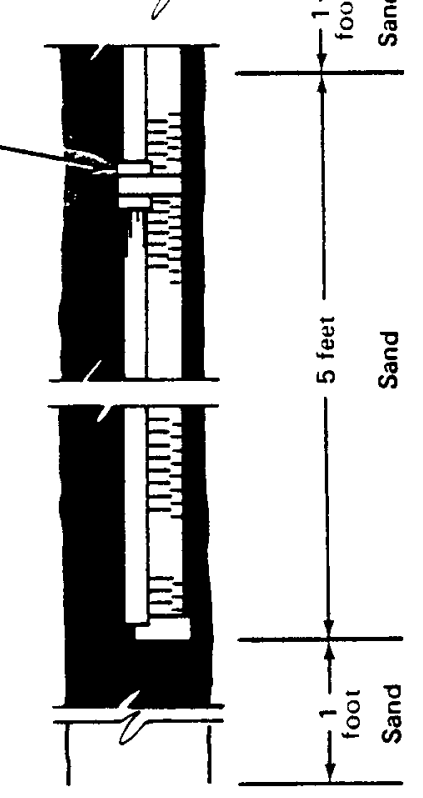

\begin{tabular}{|c|c|}
\hline $\begin{array}{c}\text { Project No. } \\
15109\end{array}$ & $E G \& G$ \\
\hline
\end{tabular}




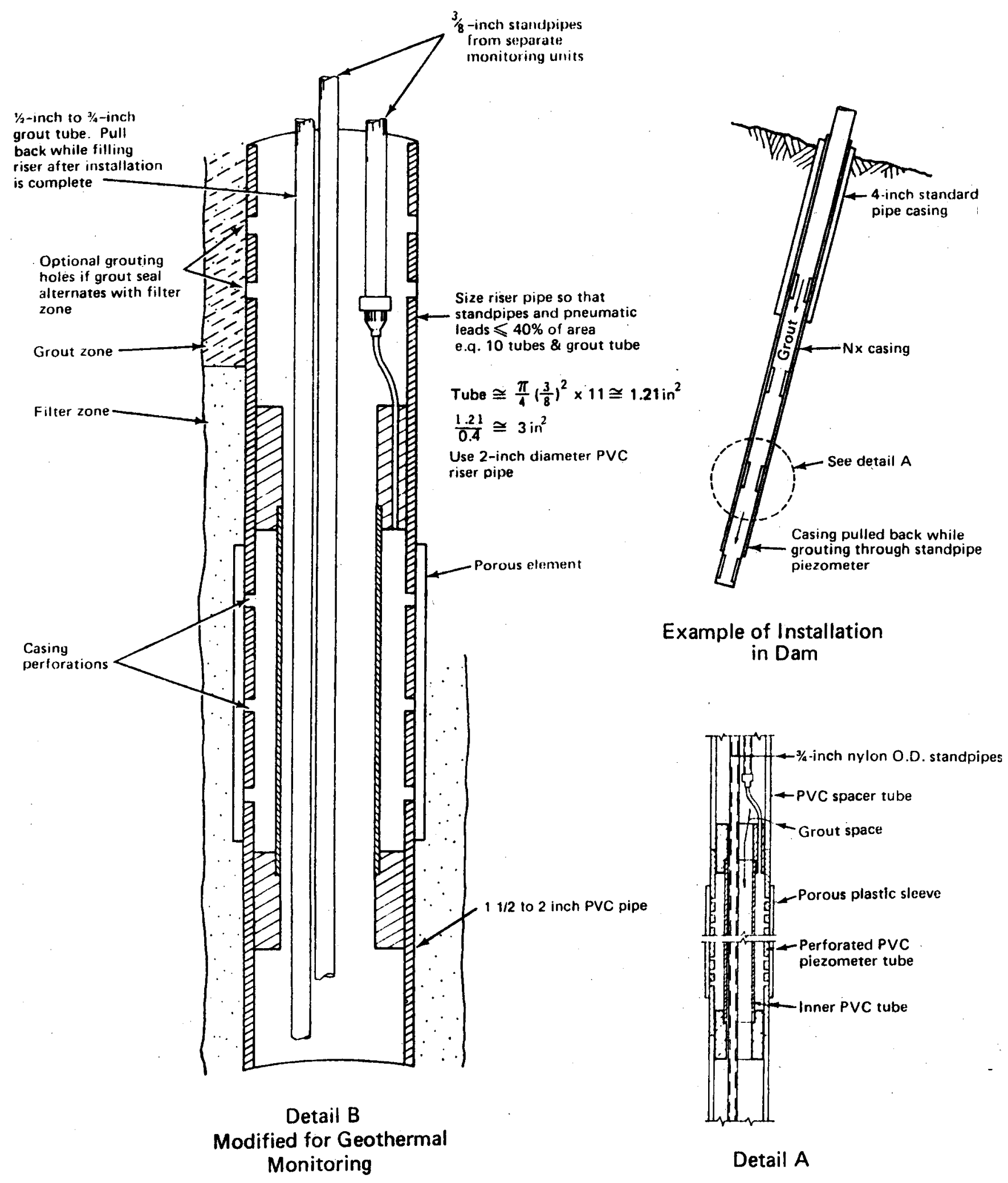

No Scale

\begin{tabular}{|c|c|c|c|}
\hline $\begin{array}{c}\text { Project No. } \\
15109\end{array}$ & $E G \& G$ & \multirow{2}{*}{$\begin{array}{c}\text { MULTIPLE UNIT STANDPIPE PIEZOMETER } \\
\text { (After Vaughn, 1969) }\end{array}$} & \multirow{2}{*}{$\begin{array}{l}\text { FIGURE } \\
2\end{array}$} \\
\hline \multicolumn{2}{|c|}{ 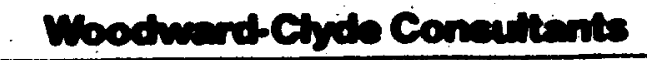 } & & \\
\hline
\end{tabular}




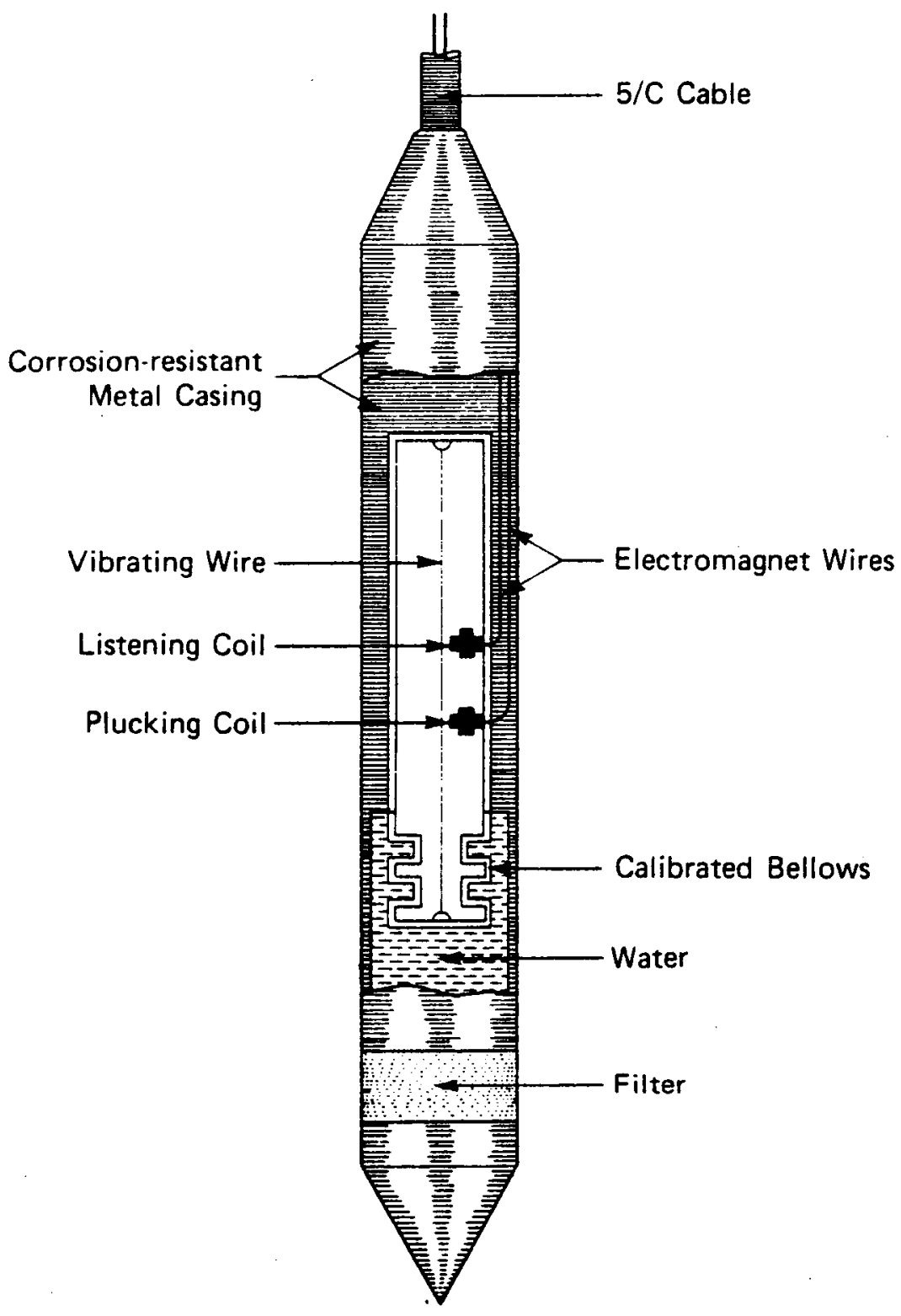

Project No. 15109 


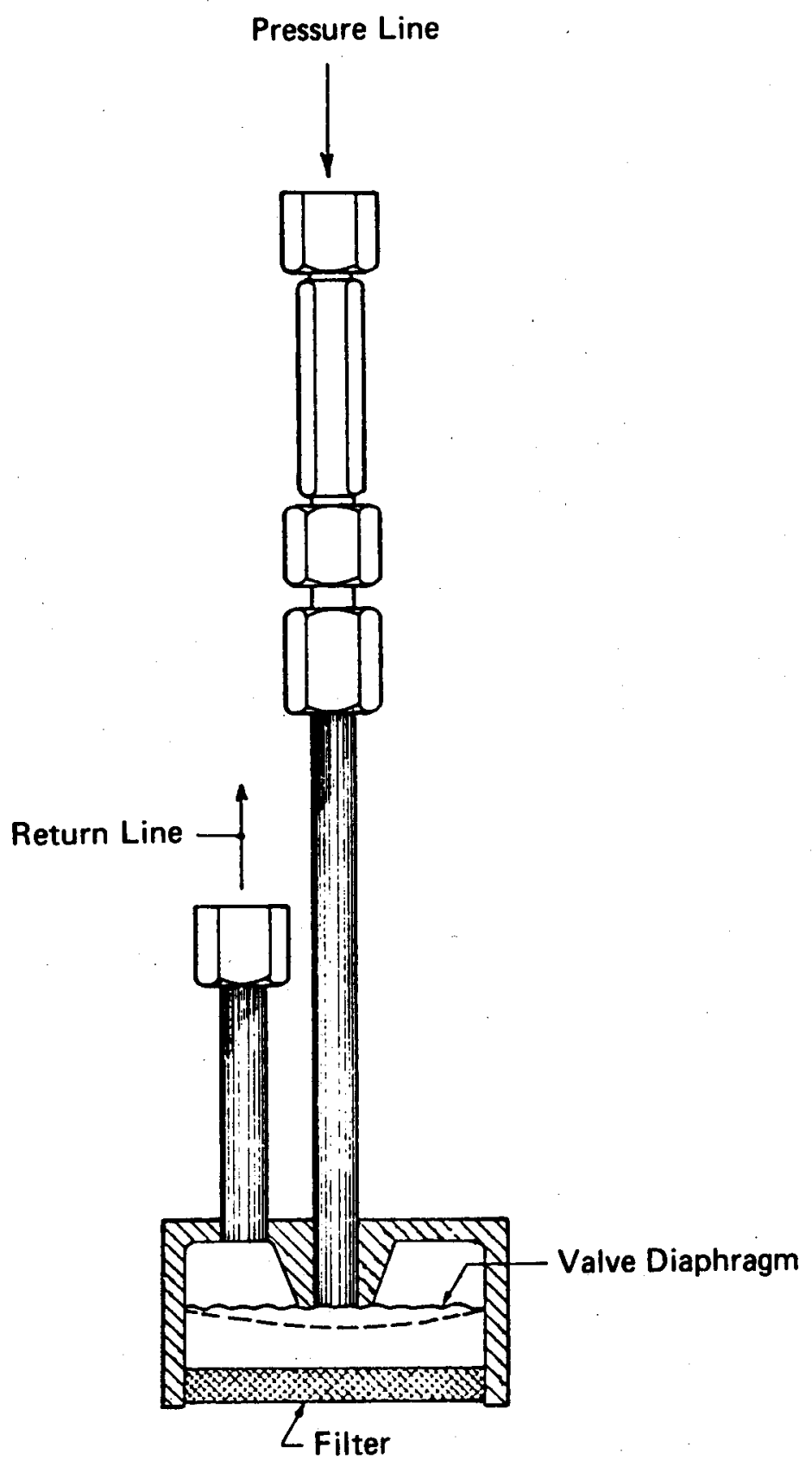

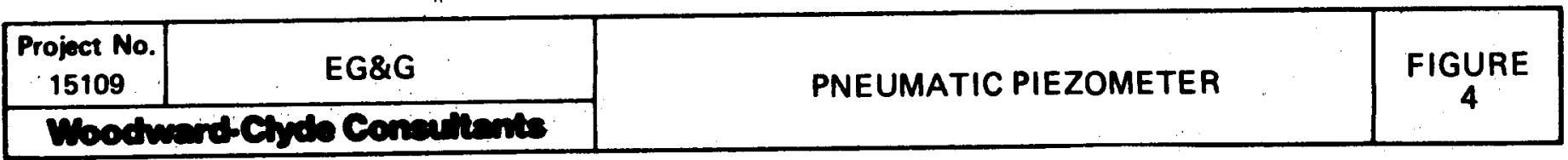



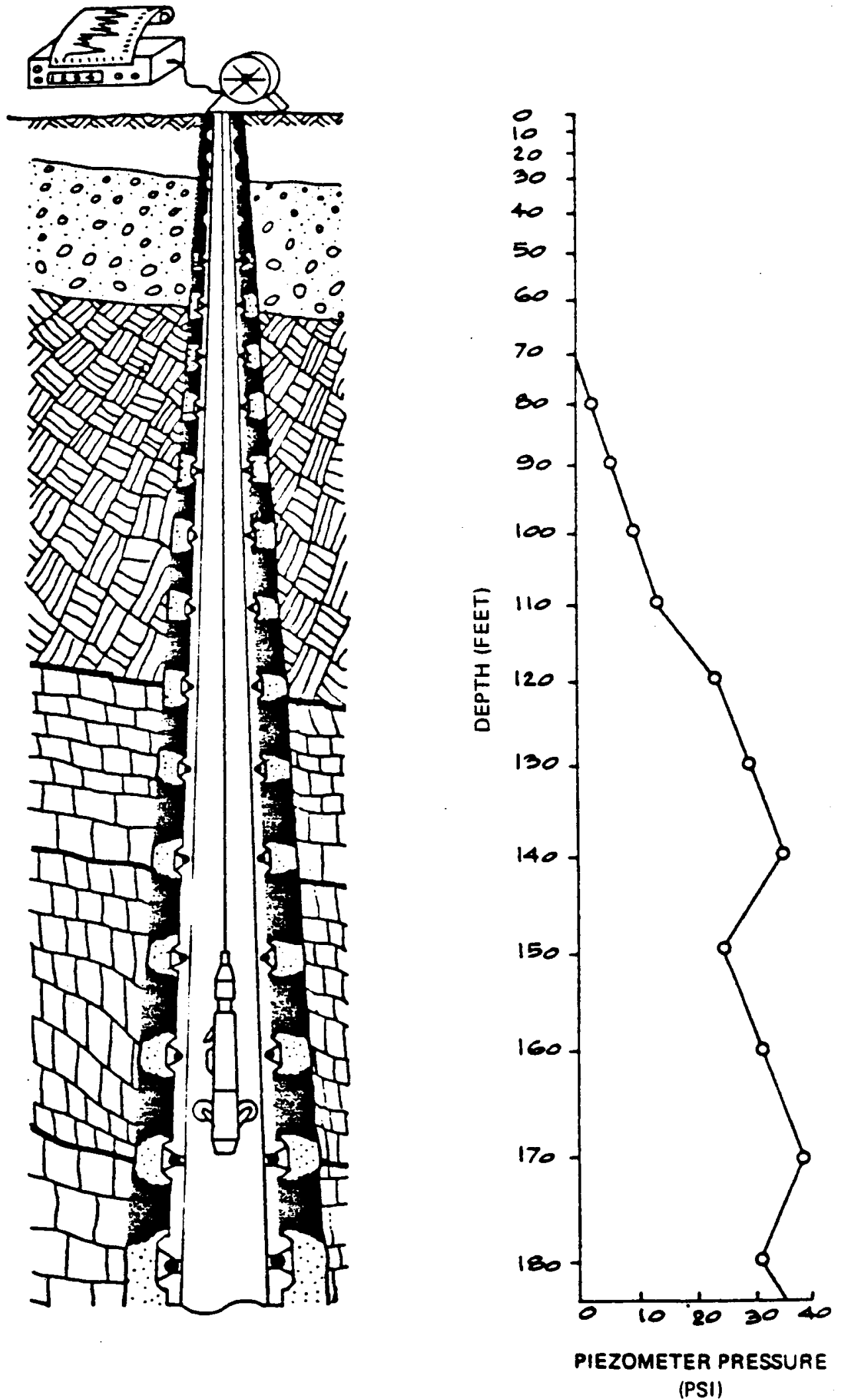

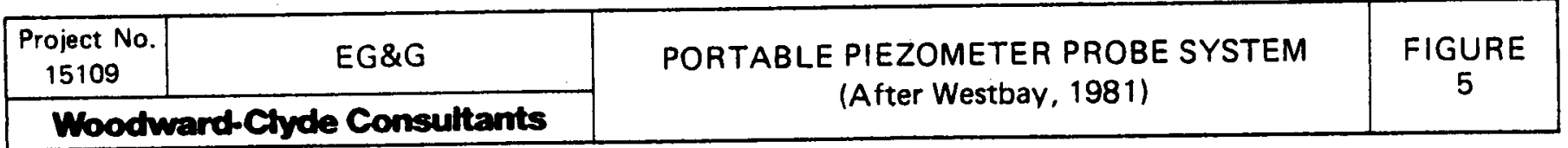




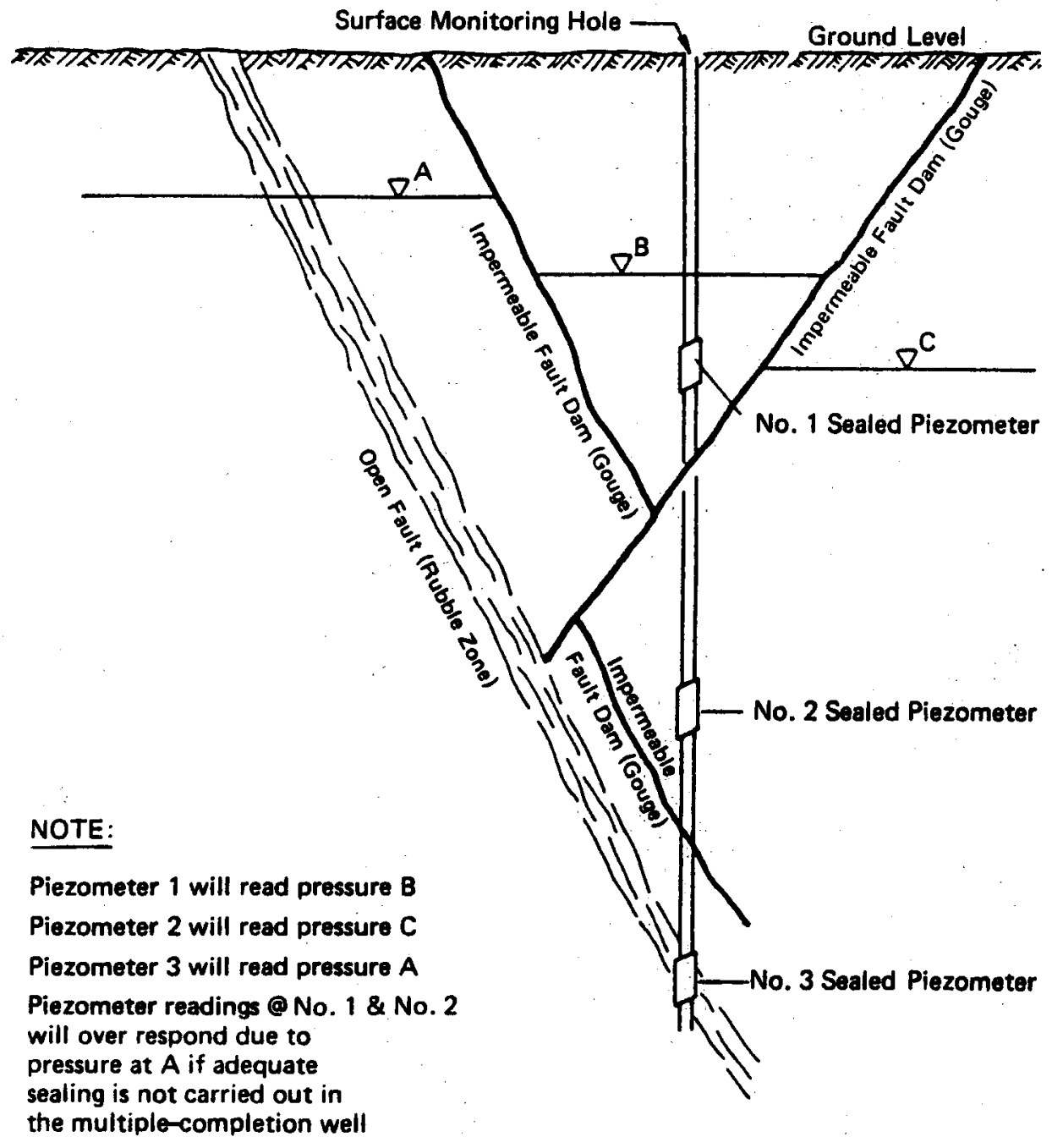

\begin{tabular}{|c|c|}
\hline $\begin{array}{c}\text { Project No. } \\
15109\end{array}$ & EG\&G \\
\hline Woodword-Cyde Congertants: \\
\hline
\end{tabular}




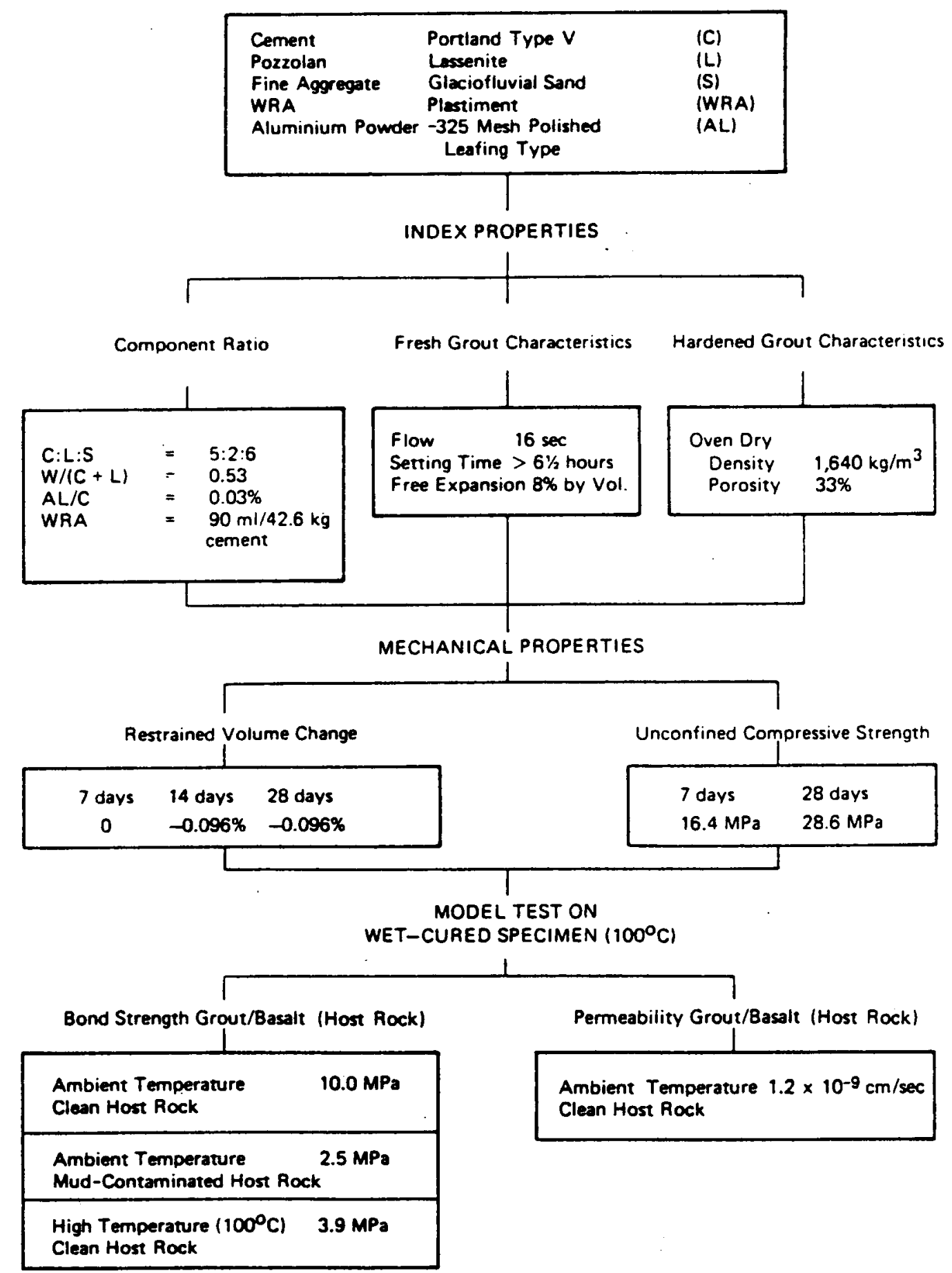

\begin{tabular}{|c|c|c|c|}
\hline $\begin{array}{c}\text { Project No. } \\
15109 \\
\end{array}$ & $E G \& G$ & \multirow{2}{*}{$\begin{array}{c}\text { SUMMARY OF GROUT PERFORMANCE } \\
\text { FOR MODERATE TEMPERATURE LOCATION } \\
\left(T<100^{\circ} \mathrm{C}\right)\end{array}$} & \multirow{2}{*}{$\underset{7}{\text { FIGURE }}$} \\
\hline \multicolumn{2}{|c|}{ Woodward-Clyde Consultants } & & \\
\hline
\end{tabular}




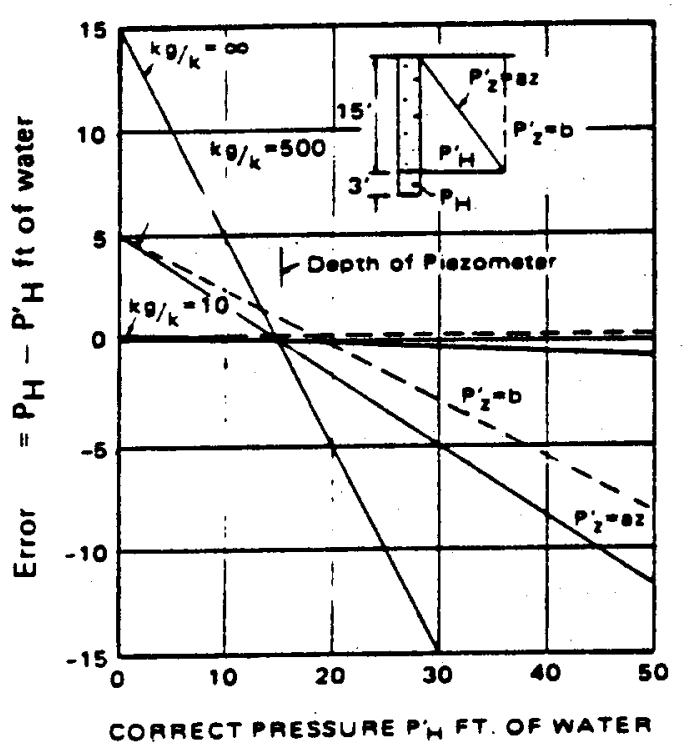

(a) Variation of piezometer error with pressure, $r_{0}=10$ feet, $r_{w}=3$ inches

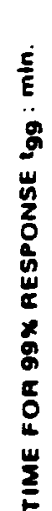

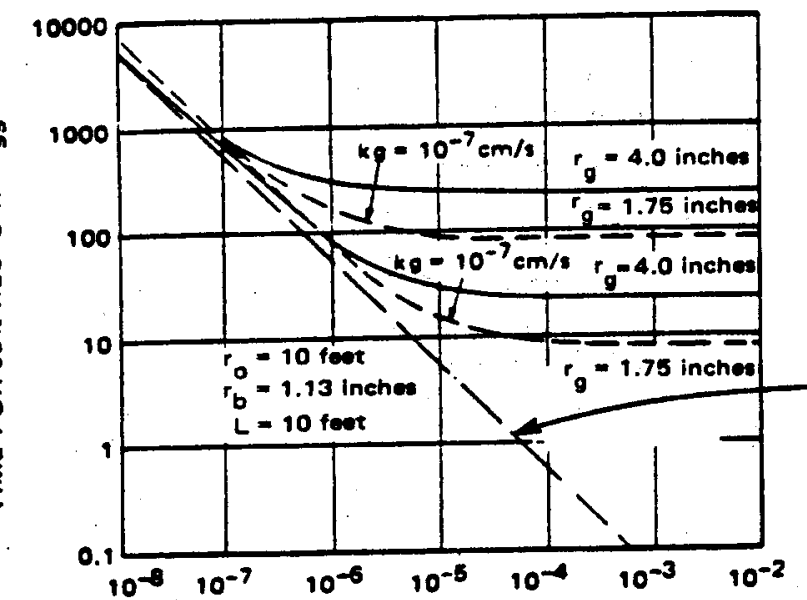

PERMEABILITY OF GROUND K:cm/s

(c) Response times of standpipe piezometers pleced in grout

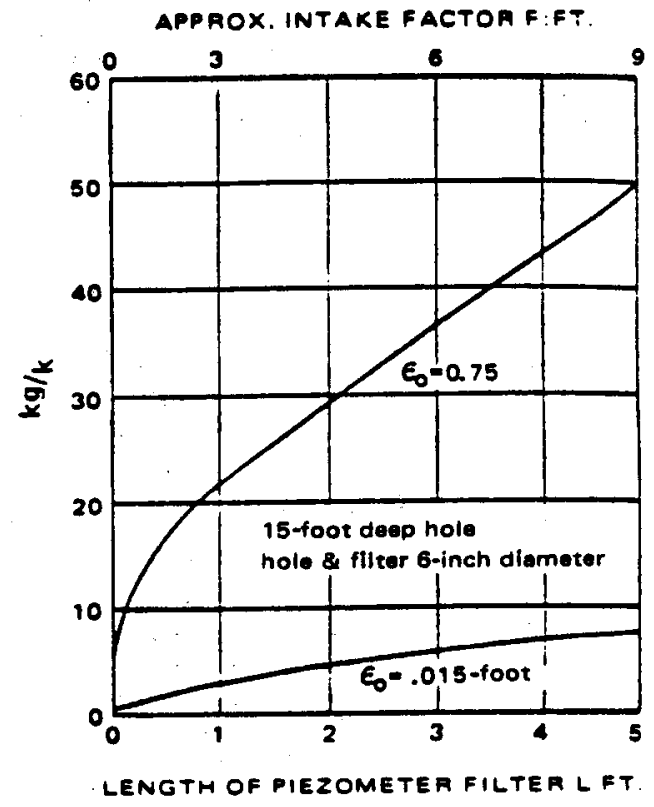

(b) Variation of piezometer error with length of filter

\section{SYMBOLS}

$k_{g}=$ grout permeability

$k$ = ground permeability

$\epsilon_{0}$ - piezomoter error for any practical piezometer geometry: $\epsilon_{0}$ is independent of depth for endl errors.

$r_{0}=$ hydraulic redius of influence of well

$r_{w}=$ redius of wetl

$P_{H}=$ observed pressure of at depth $H$ $P_{H}^{\prime}=$ true pressure at depth $H$

Response for conventional piezometer with and filter of redius 1.75 inches

$E=$ piezometer error

$=P_{H}-P_{H}$

$=\epsilon_{O}-n^{\prime} P_{H}$

For small orrors, it is sufficient to require $\epsilon_{0}$ to be small, which is a function of piezometer geometry 4 shown in (b).

U.S. Equivalents:

$3.28 \mathrm{ft}=1 \mathrm{~m}$

1 inch $=2.54 \mathrm{~cm}$

$1 \mathrm{~m} / \mathrm{sec}=2.121 \times 10^{6}$

U.S. gallons/day/feet ${ }^{2}$ 


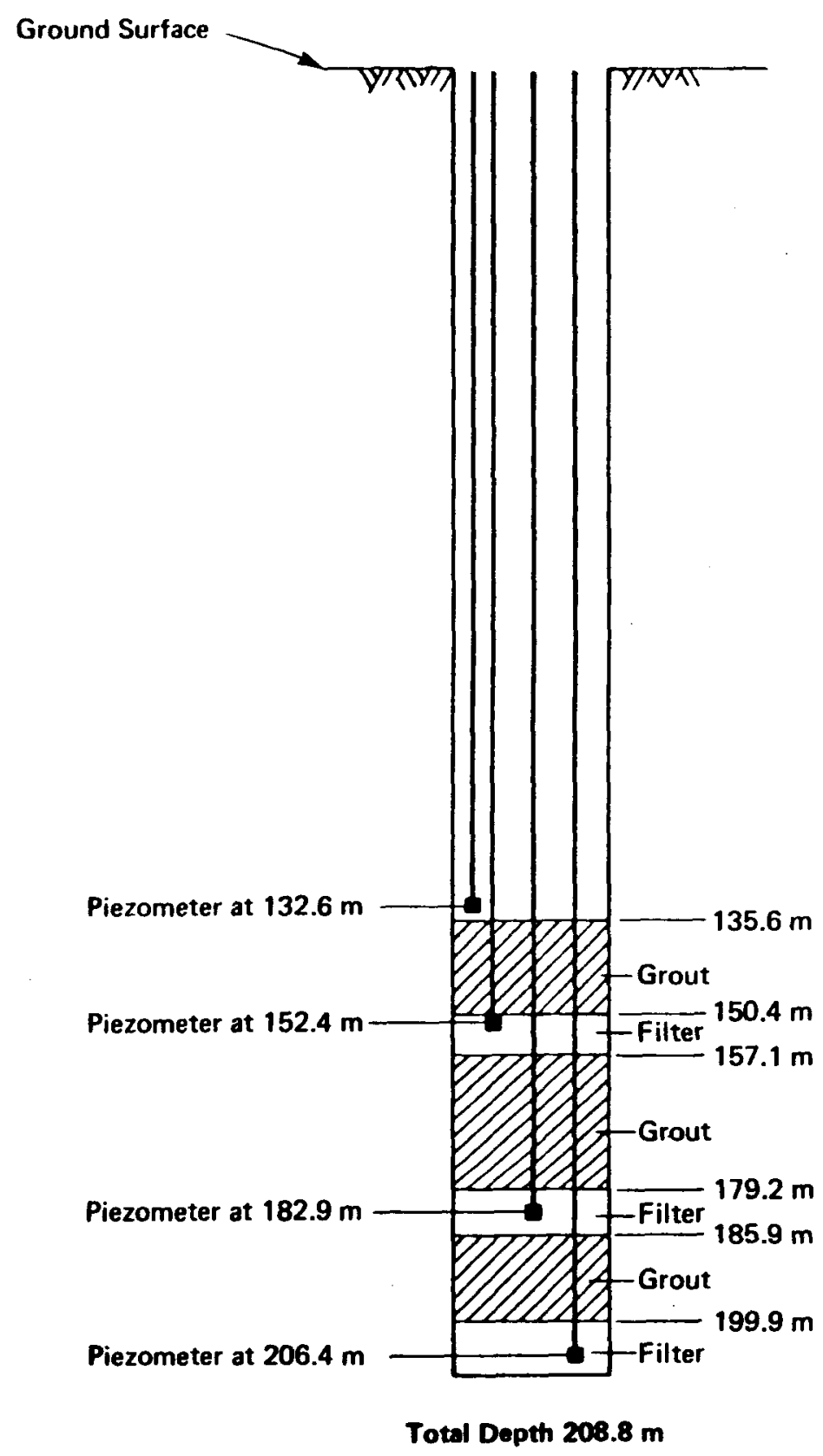

U.S. Equivalents:

$3.28 \mathrm{ft}=1 \mathrm{~m}$

$2.54 \mathrm{~cm}=1 \mathrm{inch}$

\begin{tabular}{|c|c|c|c|}
\hline $\begin{array}{c}\text { Project No. } \\
15109\end{array}$ & EG\&G & \multirow{2}{*}{$\begin{array}{l}\text { MULTIPLE-COMPLETION WELL EXAMPLE } \\
\text { (After Deardorff and others, 1980) }\end{array}$} & \multirow{2}{*}{$\underset{9}{\text { FIGURE }}$} \\
\hline \multicolumn{2}{|c|}{ Woodward-Cyde Consultants } & & \\
\hline
\end{tabular}




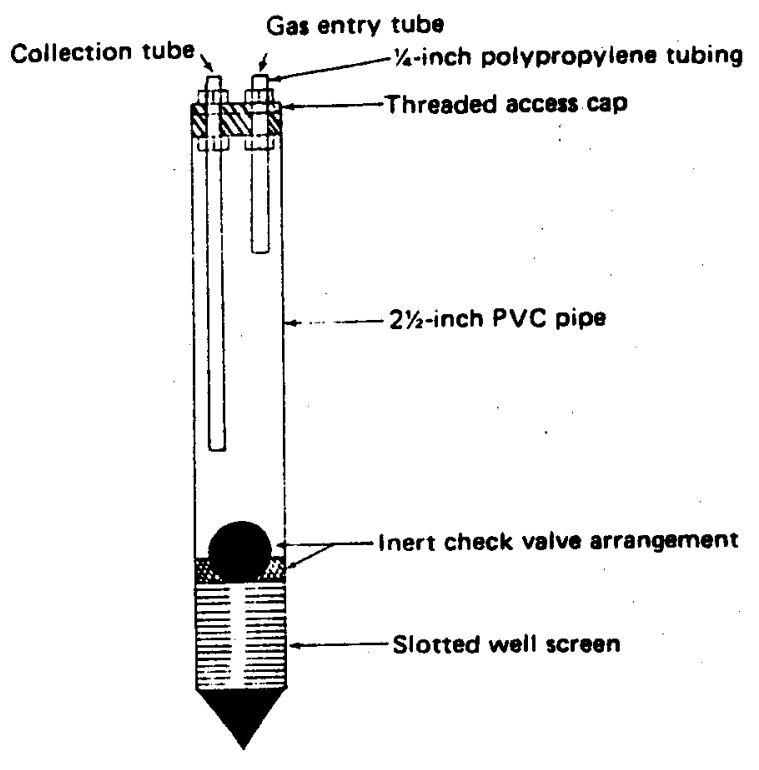

(a) COARSE SEDIMENTS

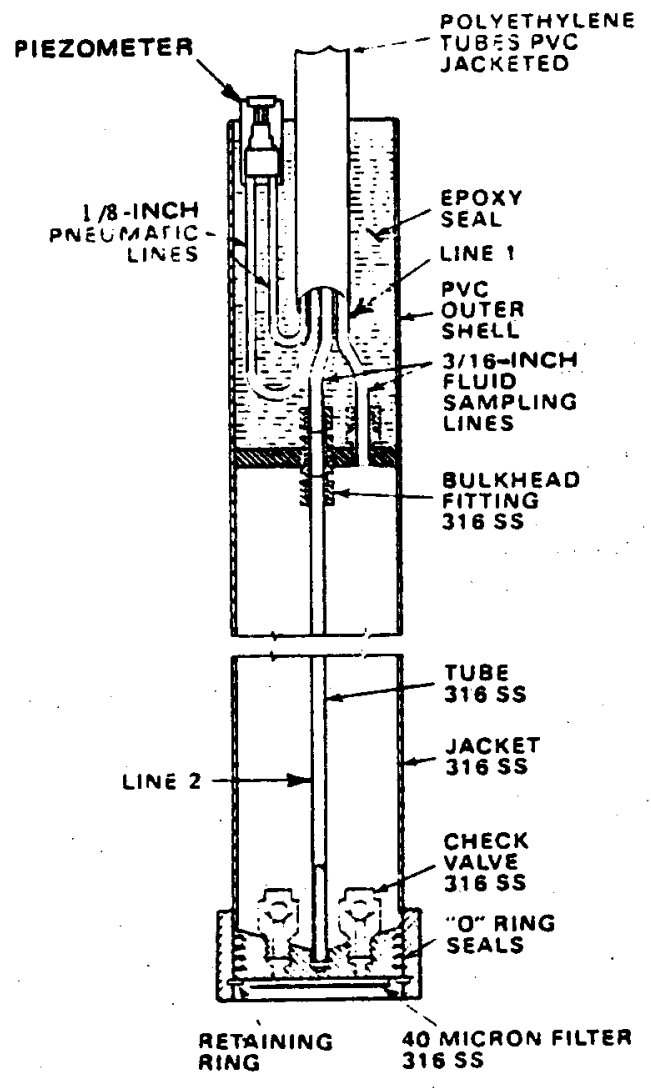

(c) COMBINED WITH PIEZOMETER FOR PRESSURE MONITORING

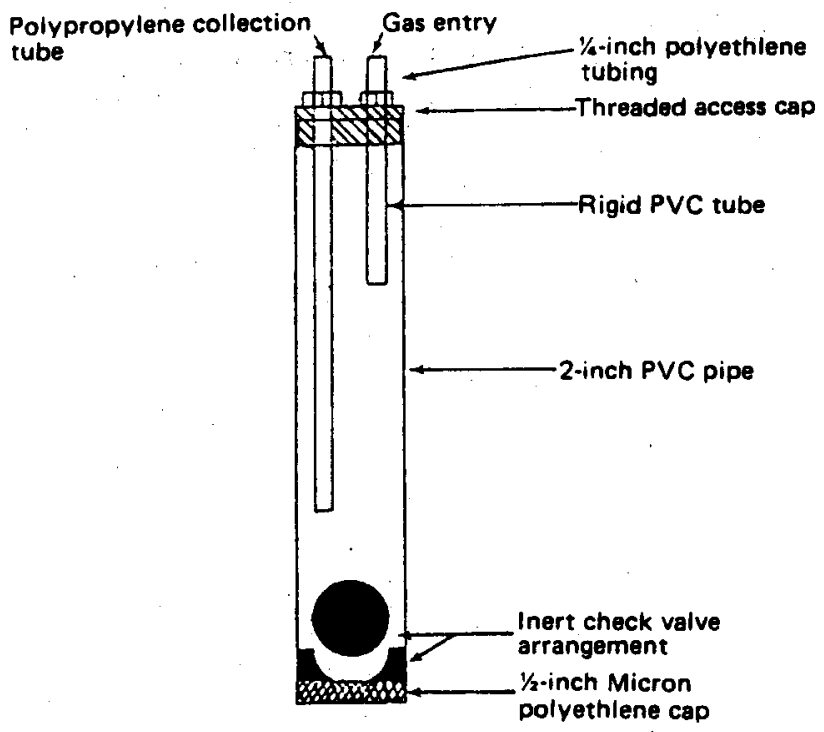

(b) FINE SEDIMENTS

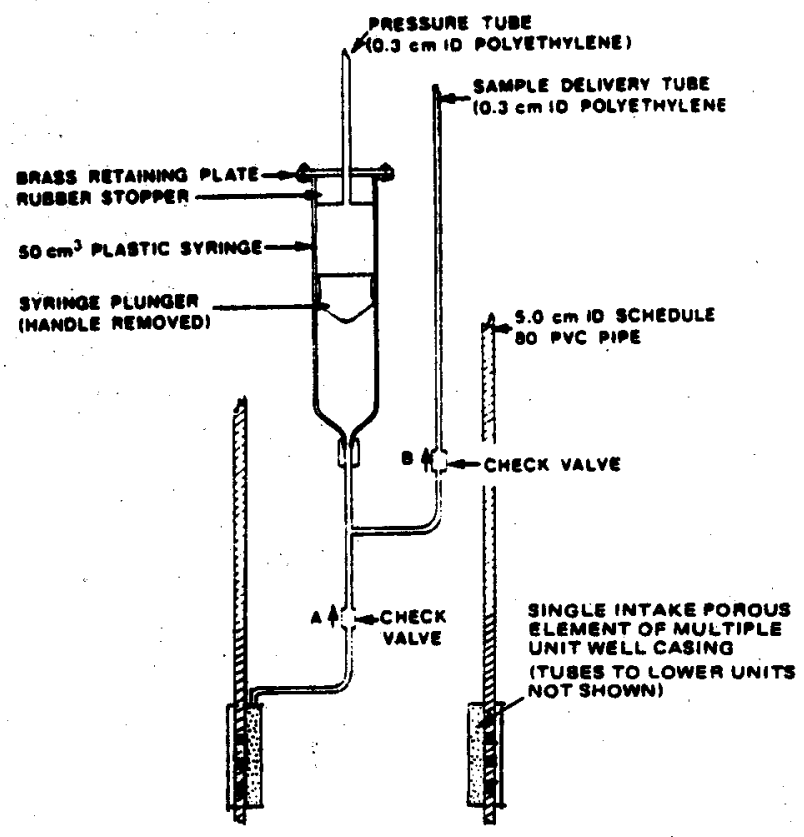

(d) COMBINED WITH MULTIPLE-UNIT STANDPIPE PIEZOMETER INSTALLATION

\begin{tabular}{|c|c|c|c|}
\hline $\begin{array}{c}\text { Project No. } \\
15109\end{array}$ & $E G \& G$ & \multirow{2}{*}{$\begin{array}{l}\text { SCHEMATICS OF AIR-LIFT WATER QUALITY } \\
\text { SAMPLERS }\end{array}$} & \multirow[t]{2}{*}{$\begin{array}{c}\text { FIGURE } \\
10\end{array}$} \\
\hline Woodin & Conmilinus & & \\
\hline
\end{tabular}




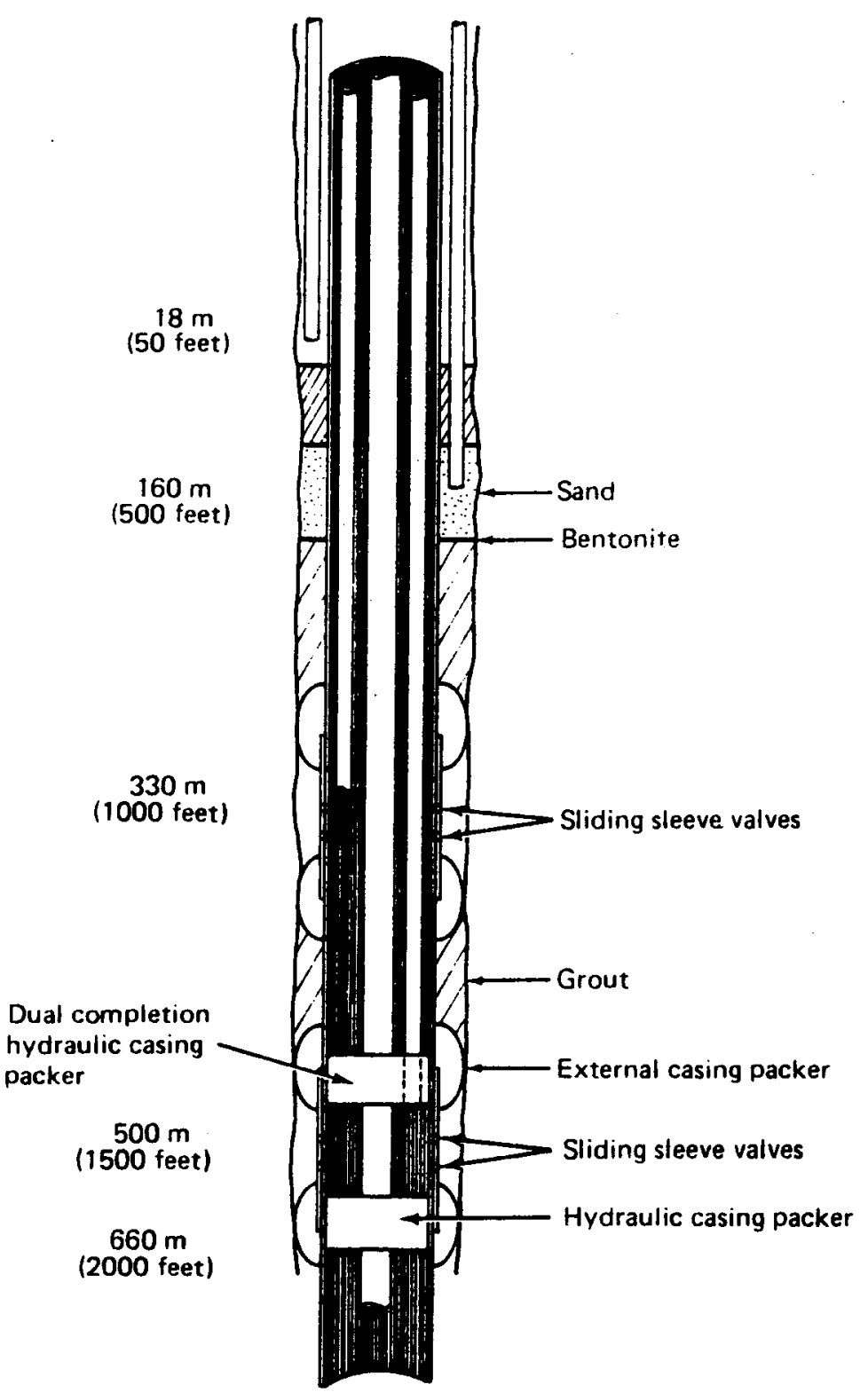

Not to scaie

\begin{tabular}{|c|c|c|c|}
\hline $\begin{array}{c}\text { Project No. } \\
15109 \mathrm{~A}\end{array}$ & EG\&G & \multirow{2}{*}{ SKETCH OF PACKER SYSTEM } & \multirow{2}{*}{$\underset{11}{\text { FIGURE }}$} \\
\hline Moodn & Connming & & \\
\hline
\end{tabular}




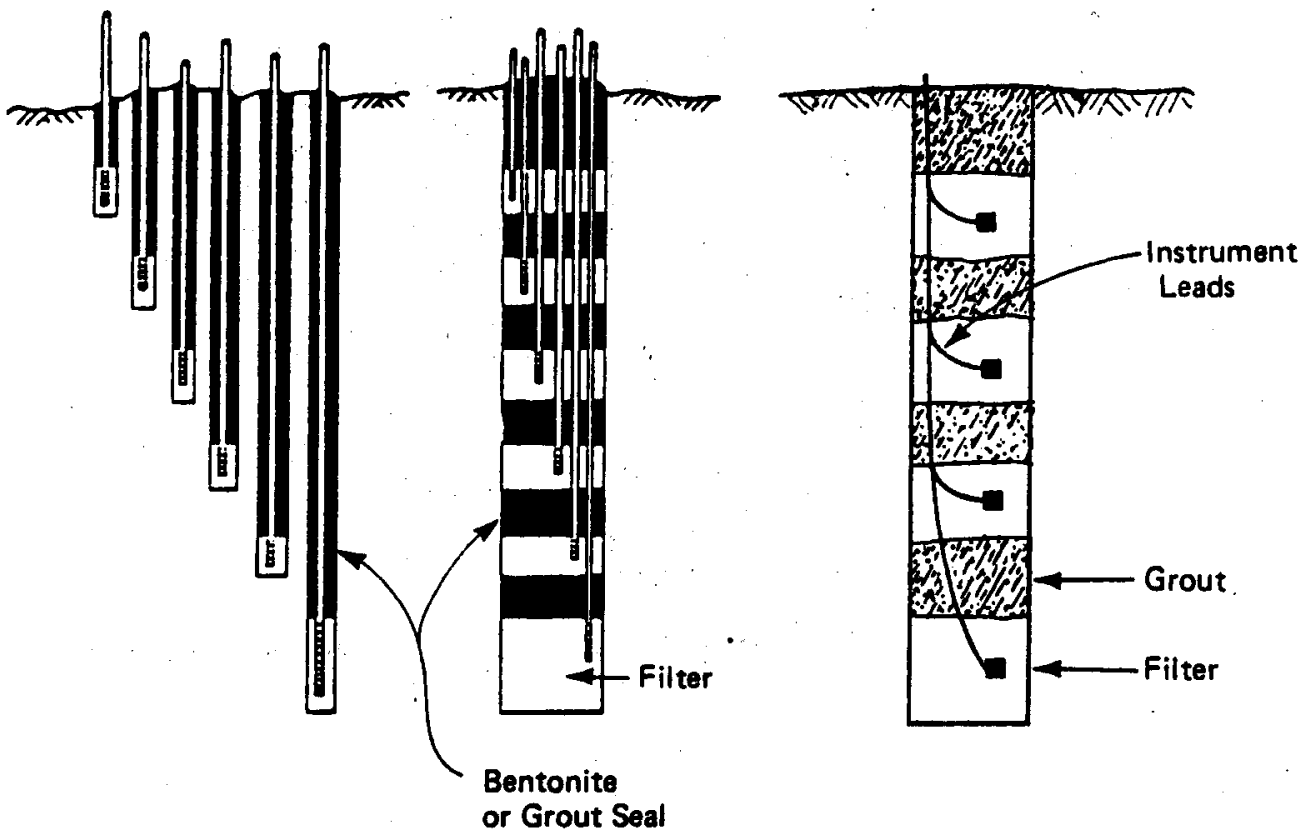

(a) Nest of single standpipe piezometers (b) Single drillhole with conventional multiple standpipe piezometer completion (c) Single drillhole with multiple closed piezometers with water sampling 